\title{
Proteomics and Pathway Mapping Analyses Reveal Phase-Dependent Over-Expression of Proteins Associated with Carbohydrate Metabolic Pathways in Candida albicans Biofilms
}

\author{
Ali Abdul Lattif ${ }^{1}$, Jyotsna Chandra ${ }^{1}$, Jinsook Chang ${ }^{2}$, Shuqing Liu², Guangyin Zhou ${ }^{1}$, Mark R. \\ Chance $^{2}$, Mahmoud A. Ghannoum ${ }^{1}$ and Pranab K. Mukherjee ${ }^{1, *}$ \\ ${ }^{1}$ Center for Medical Mycology, Department of Dermatology and ${ }^{2}$ Center for Proteomics, Case Western Reserve Univer- \\ sity, Cleveland, $\mathrm{OH}$, USA
}

\begin{abstract}
Candida albicans is the most commonly isolated fungus associated with biofilms, which are extracellular matrix (ECM)-encased, drug-resistant microbial communities formed on indwelling medical devices. Protein profiles of fungal biofilms have not been investigated in detail, although such profiles are believed to play critical roles in fungal biofilm formation. In this study, we used two-dimensional difference-in-gel electrophoresis (DIGE)-based proteomics to identify differentially expressed proteins in C. albicans biofilms grown to early and mature phases, compared to planktonic cells. The resulting proteomic data set was subjected to pathway mapping to reveal phase-specific pathways that were differentially expressed in biofilm cell walls and extracellular matrix (ECM). Our analyses showed 107 proteins to be differentially expressed in ECM, while 44 were differentially expressed in cell walls during biofilm formation, compared to planktonic controls. Furthermore, 95\% (102/107) and 68\% (30/44) of these differentially expressed proteins were upregulated in ECM and cell walls of biofilms, respectively. These proteins were mapped to cellular pathways, which revealed that these differentially expressed proteins were associated with several metabolic pathways, in a phase-dependent manner. For example, among ECM-associated proteins, proteins within 18 pathways were differentially expressed, with two pathways (glutamate and nitrogen metabolism) unique to early phase, and four pathways (purine, Gly/Ser/Thr, and inositol metabolism, and carbon fixation) unique to mature phase biofilms. Such differences were also observed in cell wallassociated proteins, where proteins associated with 14 specific pathways were differentially regulated. We also found glycolytic enzymes including the key enzyme glyceraldehyde-3-phosphate dehydrogenase (GAPDH) were overexpressed in biofilms at both early and mature phases, compared to planktonic controls. Iodoacetate-mediated inhibition of this enzyme completely abrogated the ability of $C$. albicans to form biofilms, indicating the role of glycolysis/gluconeogenesis pathways in biofilm formation. Taken together, we demonstrate that ECM and cell walls of C. albicans biofilms express increased levels of specific proteins within pathways in a phase-dependent manner, suggesting that these pathways, especially glycolysis/gluconeogenesis, play critical roles in fungal biofilm formation and maintenance.
\end{abstract}

\section{INTRODUCTION}

Candida albicans is the fourth most common cause of bloodstream infections in the U.S. [1,2], and has a noticeably high attributable mortality rate $(40 \%-49 \%)$ among patients with catheter-related candidemia $[3,4]$. Candida infections associated with central venous catheters (CVCs) commonly involve formation of biofilms (communities encased within a carbohydrate-rich extracellular matrix, ECM) on surfaces of indwelling medical devices. These biofilms represent a protected niche for fungal cells where they can evade both the host immune system and antimicrobial agents. Current practice guidelines for Candida-associated catheter infections recommend removal of catheter for management of catheter-associated infections $[5,6]$. Unfortunately, CVCs cannot be removed easily because of the need for continued blood drawing, administration of blood products and antibiotics and continuous infusion of total parenteral nutrition. Therefore, a critical need exists to understand the biology and pathogenesis of Candida biofilms, in

*Address correspondence to this author at the Center for Medical Mycology, Department of Dermatology, Case Western Reserve University, Cleveland, OH, USA; E-mail: Pranab.Mukherjee@case.edu order to develop effective strategies to manage such infections.

Candida biofilms form in three distinct developmental phases: early, intermediate, and mature. The morphology and architecture of Candida biofilms vary with their developmental phases, with mostly adherent cells and microcolonies observed in the early phase $(6 \mathrm{~h})$, and appearance of profuse, carbohydrate-rich matrix in the mature phase $(48 \mathrm{~h})$ [7]. In addition, early phase biofilms exhibit reduced susceptibility to antifungals, while mature biofilms are rendered completely resistant to most antifungals [8].

Biofilm-specific proteins are believed to be critical determinants of the morphological and architectural characteristics, and resistance phenotype of fungal biofilms. Technological advances in proteomics have allowed the identification of large-scale changes in protein profiles of biological systems, including microbial biofilms [9-13]. Recently, we performed proteomic analysis of cell walls of mature biofilms formed on catheter discs using two-dimensional difference-in-gel electrophoresis (DIGE), and showed that biofilm cell walls (as compared to planktonic cells) express differential levels of various proteins, including alcohol dehydrogenase (Adh1p) [14]. In a separate study, Thomas et al. [15] 
used the traditional two-dimensional gel electrophoresis (2DGE)-based proteomic approach and identified proteins that were differentially expressed in mature $C$. albicans biofilms formed on surfaces of tissue culture flasks. However, the effect of developmental phases on changes in the proteomic profile of catheter-associated Candida biofilms has not been investigated.

The state-of-the-art technique of DIGE allows precise analysis of differences in protein abundance between samples [16], with accurate spot matching among multiple gels. In the current study, we used this robust technique to identify biofilm-associated proteins expressed at early and mature phases of biofilm formation. Specifically we focused on proteins present in cell walls and ECM compartments of Candida biofilms, since these proteins may be novel targets that can be exploited to develop diagnostic and/or therapeutic markers.

In this study, we isolated cells walls and ECM from Candida biofilms and planktonic cells using SDS- and EDTAbased extraction methods, respectively, and performed DIGE-based proteomic analyses to identify proteins expressed differentially in biofilms. Furthermore, we performed functional mapping of these differentially expressed proteins to pathways to identify pathways that are potentially overexpressed in biofilms. Finally, we determined the effect of an inhibitor associated with one of the overexpressed pathways (glycolysis) on the ability of $C$. albicans to form biofilms. We found that EDTA-treatment was most efficient method to isolate ECM from Candida biofilms. Our DIGE analyses showed 151 proteins were differentially expressed in ECM and cell walls of Candida biofilms, compared to planktonically grown cells. Pathway mapping analyses revealed that majority of the differentially expressed proteins were associated with metabolic pathways, in a phasedependent manner. Inhibitor-based assays suggested a role for glyceraldehyde-3-phosphate (GAPDH) in biofilm formation. These results suggested that glycolytic pathway and GAPDH play critical roles in Candida biofilm formation.

\section{MATERIALS AND METHODS}

\section{Strain}

C. albicans SC5314 was used in all experiments described in this study. Candida cells were grown overnight at $37^{\circ} \mathrm{C}$ in yeast nitrogen base medium (YNB, Difco laboratories, Detroit, MI). Cells were harvested, washed with phosphate-buffered saline (PBS) and standardized to $1 \times 10^{7}$ cells $/ \mathrm{ml}$.

\section{Biofilm Formation}

Biofilms were formed on silicone elastomer (SE) discs using our catheter-based in vitro model as described previously [7]. Briefly, SE discs (diameter $12 \mathrm{~mm}$ ) were precoated with fetal bovine serum (FBS), and immersed in $4 \mathrm{ml}$ of a standardized C. albicans cell suspension $\left(1 \times 10^{7}\right.$ cells $/ \mathrm{ml}$ ) for 90 min to allow adhesion of fungal cells to the substrate. The catheter discs containing adhered Candida cells were then placed in fresh YNB medium in a 12-well tissue culture plate and allowed to form biofilms to early (6 h) or mature $(48 \mathrm{~h})$ developmental phases. Biofilms were quantified by a tetrazolium-salt (XTT) - based assay, as described previously $[7,17]$. Planktonic cells were grown simi- larly in tissue culture plates with the difference that no catheter discs were present.

\section{Isolation of Biofilm Matrix}

A pre-requisite to determining the protein profile of biofilm ECM is to identify an optimal method that can result in maximum protein yield, which will be suitable for investigating subtle protein-protein interactions involving low-yield proteins in the biofilm matrix. Therefore, we compared the protein yields of ECM isolated using five different methods $[18,19]$. The first method (i) was based on centrifugation of scraped biofilms at $10,000 \mathrm{~g}$, followed by collection of supernatant. In the remaining four methods, initially the biofilms were scraped into PBS, and they were then: (ii) incubated with $10 \mathrm{mM}$ EDTA for $2 \mathrm{~h}$ at $4^{\circ} \mathrm{C}$ with gentle shaking, (iii) ultrasonicated for $10 \mathrm{~min}$, (iv) ultrasonicated for 2 min followed by vortexing for $10 \mathrm{~min}$, or (v) vortexed for 10 min (for schematic, see Fig. 1A). After each of these treatments, the sample was centrifuged at $10,000 \times \mathrm{g}$. The resulting supernatant was collected, filtered through a $0.22 \mu \mathrm{m}$ diameter filter, and stored at $-20{ }^{\circ} \mathrm{C}$ until further analysis. To determine whether treatment with the five isolation methods induced cell death, biofilms were collected, exposed to the five different methods, and then spread on Sabouraud dextrose agar for quantitative culturing. Agar plates were incubated at $37^{\circ} \mathrm{C}$ for $24 \mathrm{~h}$ and the number of colony forming units (CFUs) counted.

\section{Isolation of Biofilm Cell Walls}

Cell walls were isolated from Candida biofilms and their labile proteins were solubilized by treatment with SDS as described previously $[14,20]$. This method has previously been used by our group and other investigators to separate soluble and insoluble cell wall proteins of Candida cells [2022]. Briefly, biofilms and planktonic cells were harvested, washed with prechilled PBS, and homogenized with glass beads $(0.45-\mathrm{mm}$ diameter; Sigma) in buffer A $(10 \mathrm{mM}$ sodium acetate, $\mathrm{pH}$ 5.0, $1 \mathrm{mM}$ phenylmethylsulfonyl fluoride). The resulting lysate was centrifuged to remove cytoplasmic material, and the cell wall pellet was incubated with buffer B (10 mM Tris-Cl, pH 7.8, 2\% SDS, $100 \mathrm{mM}$ EDTA, $40 \mathrm{mM}$ $\beta$-mercaptoethanol) for $10 \mathrm{~min}$ at $100^{\circ} \mathrm{C}$ to release SDSsoluble cell wall (CWS) proteins into the mixture. These released CWS proteins were collected after a brief centrifugation step in the supernatant and processed for proteomic analyses.

\section{Determination of Protein, Carbohydrate and DNA Con- tent}

Total protein content was determined using BioRad Protein Assay kit (BioRad laboratories) and bovine serum albumin (BSA) as standard, while total carbohydrate content was determined using phenol sulfuric acid method, with glucose as standard [23]. Extracellular DNA (eDNA) content was determined using the diphenylamine reaction [24].

\section{Proteomic Analyses}

\section{(i) Two-Dimensional Difference-in-Gel Electrophoresis (DIGE)}

The DIGE technique circumvents problems associated with traditional two-dimensional gel electrophoresis (2D- 
GE) by allowing simultaneous resolution of two different protein samples (plus an internal standard) in the same gel. We used the DIGE approach to analyze cell wall and ECM proteins isolated from C. albicans grown as biofilm or planktonic cells to early $(6 \mathrm{~h})$ or mature $(48 \mathrm{~h})$ time points $(\mathrm{n}=4$ of each experimental group, total 32 samples), as described previously by our group [14]. Protein concentration was determined using 2D-Quant Kit as described by the manufacturer (GE Healthcare Amersham Biosciences). Briefly, proteins isolated from planktonic or biofilm forms of C. albicans were labeled with $\mathrm{Cy} 3$ or $\mathrm{Cy} 5$ cyanine dyes while an internal standard was generated by pooling an aliquot of all samples which was then labeled with Cy2. Equal amounts of protein were loaded onto the gel for IEF and gel electrophoresis. A dye-swapping scheme was used such that 2 of 4 replicates were labeled with $\mathrm{Cy} 3$ and 2 of 4 replicates were labeled with Cy5. Labeling was performed by incubation with $400 \mathrm{pmol}$ of Cy dye per $50 \mu \mathrm{g}$ of protein for $30 \mathrm{~min}$ on ice in the dark, the reaction was then quenched with $10 \mathrm{mM}$ lysine and additionally incubated for $10 \mathrm{~min}$. The three differently labeled samples were mixed together and an additional 200 $\mu \mathrm{g}$ of unlabeled protein pooled from each sample added to increase the amount of protein available for spot picking and identification.

Rehydration of the isoelectric $\mathrm{pH}$ gradient (IPG) strips (pH 3-10, $24 \mathrm{~cm}$, GE Healthcare) with protein samples was performed in rehydration buffer containing $8 \mathrm{M}$ Urea, $4 \%$ CHAPS, bromophenol blue, $1 \%$ Phamalyte, and $2 \mathrm{mg} / \mathrm{ml}$ DTT using the IPGphor IEF system (GE Healthcare), followed by isoelectric focusing using IPGphor II (GE Healthcare) for a total of $65.5 \mathrm{kVh}$. The gel strips were then equilibrated for $2 \times 15$ minutes with gentle shaking in equilibration solution containing $50 \mathrm{mM}$ Tris-Cl buffer, $6 \mathrm{M}$ urea, $30 \%$ glycerol, $2 \%$ SDS, and bromophenol blue. DTT (1\% w/v) was added to the first, and iodoacetamide $(2.5 \% \mathrm{w} / \mathrm{v})$ to the second equilibration step to reduce and carbamidomethylate cysteine sulfhydryls. IPG strips were then placed on top of $12.5 \%$ homogeneous polyacrylamide gels that were precasted with low-fluorescence glass plates. SDS polyacrylamide gel electrophoresis in the second dimension was carried out in the dark at $1 \mathrm{~W}$ per gel for 2 hours then followed by $2 \mathrm{~W}$ per gel constant power at $14^{0} \mathrm{C}$ until bromophenol blue dye front runs off. Labeled proteins were visualized using the Typhoon 9410 imager (GE Healthcare). The fluorescence images were individually captured using excitation/emission wavelengths of $488 / 520 \mathrm{~nm}, 532 / 580 \mathrm{~nm}$, and $633 / 670 \mathrm{~nm}$ for cy2, cy3, and cy5 respectively.

\section{(ii) Image Analyses, Spot Detection, and Cluster Analysis}

The DeCyder v6.5 2D Differential Analysis Software (GE Healthcare) was used for image analysis including spot detection, background subtraction, matching, and normalization. Briefly, intra-gel spot detection and quantification of individual $\mathrm{Cy} 2, \mathrm{Cy} 3$ and $\mathrm{Cy} 5$ images of the same gel was performed in DIA (Differential-In-gel Analysis) module and subsequent inter-gel analysis including matching and statistical analysis was performed in BVA (Biological Variation Analysis). Protein profiles of biofilms grown to early and mature phases were compared with that of planktonic cells grown to the same time points. Differential protein expression between planktonic and biofilm of $C$. albicans grown to $6 \mathrm{~h}$ and $48 \mathrm{~h}$ were selected based on two-way ANOVA analyses $(P<0.05)$. Hierarchical clustering was performed using Stanford University software Cluster 2.11 [25]. Normalized volume of protein spots were extracted from DeCyder and transformed to two based log for the cluster analyses. The clustering results were obtained based on average linkage with one minus Pearson correlation distance metrics. Expression of clustered protein spots was visualized using Java Treeview [26].

\section{(iii) Mass Spectrometry Analyses}

Prior to protein excision the gel was fixed in $10 \%$ methanol and 7\% acetic acid for 10 minutes, followed by deep purple staining. This post-stain visualizes ca. $95 \%$ of the unlabeled protein and ensures accurate protein excision, as the molecular weight of $\mathrm{Cy}$-dyes can influence protein migration during SDS-PAGE. A Typhoon 9410 variable mode imager with excitation at $532 \mathrm{~nm}$ and emission filter of 610BP30 (Molecular Probes) was used to scan the gels. Proteins of interest were excised using an Ettan Spot Picker (GE Healthcare) and then digested with sequencing-grade trypsin (Promega Corp., Madison, WI). Tandem mass spectra of digested peptides were acquired using Fourier Transform LTQ mass spectrometer (FT-LTQ, Thermo Electron Corp., Bremen, Germany) equipped with HPLC system or a LTQ mass spectrometer (Thermo Electron Corp., Bremen, Germany) equipped with Ettan MDLC system (GE Healthcare). The protein digests were loaded onto trapping column (C18, PepMap100, $300 \mu \mathrm{m} \times 5 \mathrm{~mm}, 5 \mu \mathrm{m}$ particle size, $100 \AA$, Dionex) to pre-concentrate and to wash salt and then separated with a reverse phase column $(\mathrm{C} 18,75 \mu \mathrm{m} \times 150 \mathrm{~mm}, 3$ $\mu \mathrm{m}, 100 \AA$ Á, Dionex $)$, using mobile phase A $(0.1 \%$ formic acid in a water) and $\mathrm{B}(84 \%$ acetonitrile, $0.1 \%$ formic acid in water) with a linear gradient of $2 \%$ per min, starting with $100 \%$ of A. Subsequently, the peptides were infused at a flow rate of $300 \mathrm{~nL} / \mathrm{min}$ and at a voltage of $1.8 \mathrm{kV}$. MS and tandem MS spectra were acquired in the positive ion mode. A full scan recorded in the FT analyzer at resolution $\mathrm{R}=100000$ or LTQ analyzer followed by MS/MS of the eight most-intense peptide ions in the LTQ analyzer. Protein identification was determined by searching against fungi of NCBInr database using MASCOT v.2.1.03 [27]. Searches were performed with carbamidomethylation of cystein, with partial oxidation of methionine, with one missed cleavage allowed, and with mass tolerance of $15 \mathrm{ppm}$ and of $0.8 \mathrm{Da}$ for MS and MS/MS, respectively for FT-LTQ and with mass tolerance of $1.5 \mathrm{Da}$ and of $0.8 \mathrm{Da}$ for MS and MS/MS, respectively for LTQ. Protein identification was determined based on protein hits with at least two matched peptides with peptide ion score exceeding 45.

\section{Pathway Mapping}

Next we performed pathway mapping to identify differentially expressed pathways in biofilms compared to planktonic cells. When multiple proteins were matched by the online database to the same spot, the identity with maximum score was used. Differentially expressed pathways were identified using the online "Omics" tool available at http:// pathway.yeastgenome.org:8555/expression.html, and the Kyoto Encyclopedia of Genes and Genomes (KEGG) Pathway Coloring Tool (http://www.genome.jp/kegg/tool/color pathway.html) was used to color differentially expressed enzymes in specific pathways [28]. Overexpressed enzymes 
in metabolic pathways were indicated by yellow boxes, while downregulated enzymes were indicated by red boxes.

\section{Effect of GAPDH Inhibitor on C. albicans Biofilms}

To determine the role of glycolysis and glycolytic enzymes (e.g. GAPDH) in Candida biofilm formation, we evaluated the effect of sodium iodoacetate (a specific and irreversible inhibitor of GAPDH) on the ability of C. albicans to form biofilms. Biofilm formation was initiated as described above, and adherent cells were incubated in the absence or presence of $300 \mu \mathrm{M}$ sodium iodoacetate and allowed to grow under biofilm-inducing conditions for $6 \mathrm{~h}$ (early phase biofilms) or $48 \mathrm{~h}$ (mature phase biofilms). This concentration of iodoacetate was selected based on previous studies describing the inhibition of GAPDH by this inhibitor $[29,30]$. Planktonic Candida cells were grown under similar conditions. At the end of the incubation period, biofilms and planktonic cells were scraped into PBS and their dry biomass and metabolic activity were determined using dry weight determination and XTT assay, respectively, as described previously $[7,17,31]$.

\section{Confocal Scanning Laser Microscopy (CSLM)}

CSLM was used to evaluate the effect of GAPDH inhibitor on the architecture and thickness of $C$. albicans biofilms, as described previously [7]. Biofilms were grown on $\mathrm{SE}$ discs in the presence or absence of iodoacetate $(300 \mu \mathrm{M})$, and placed on a 35-mm-diameter glass-bottom Petri dish (MatTek Corp., Ashland, Mass.). Candida biofilms were stained with $\mathrm{FUN} 1^{\mathrm{TM}}$ and ConA-alexafluor dyes and observed under a Zeiss LSM510 confocal scanning laser microscope equipped with argon and $\mathrm{HeNe}$ lasers and mounted on a Zeiss Axiovert100 M microscope (Carl Zeiss, Inc.). The objective used was a water immersion $\mathrm{C}$-apochromat lens (20X). Depth measurements were taken at regular intervals across the width of the device. To determine the effect of inhibitors on the structure of the biofilms, a series of horizontal (xy) optical sections, were taken throughout the full length of the biofilm. Confocal images of green (stained with concanavalin A, ConA) and red (stained with metabolic activity indicator FUN1 ${ }^{\mathrm{TM}}$ dye) fluorescence were conceived simultaneously using a multitrack mode. Planktonically grown $C$. albicans cells were used as comparators in these studies.

\section{Statistical Analyses}

Each experiment was performed with at least three replicates. All statistical analyses were performed using StatView (version 4.5; Abacus Concepts Inc., Berkeley, CA). One-way analysis of variance (ANOVA) was performed to compare means of multiple groups, and two-tailed Student's $t$-test was used for analysis of groups. $P$ values $<0.05$ were considered statistically significant.

\section{RESULTS}

\section{EDTA Treatment Results In ECM Isolation With Maxi- mum Protein Yield}

Investigation of protein expression of low-yield proteins in the biofilm matrix is dependent on an efficient method of isolation with maximum protein yield. To optimize protein yield, we isolated proteins from biofilms and planktonically grown C. albicans using five different methods (Fig. 1A). Since biofilm ECM are known to contain carbohydrate and eDNA [32, 33], we also determined the levels of these components in the isolated Candida biofilm ECM samples. As shown in Fig. (1B), total yield of protein obtained using EDTA treatment was significantly greater than all the other methods $(P$-value $<0.05)$.

Total carbohydrate yield was lowest for centrifugation method, while no difference in eDNA yields was detected in ECM extracted using the five different methods. The effect of isolation methods on cell viability was checked by scraping biofilms and spreading the resulting suspension on Sabouraud dextrose agar, followed by counting of colony forming units (CFUs). No significant difference was found between the CFUs for any of the five treatment methods (Fig. 1C), indicating that none of the treatment methods affected viability of $C$. albicans grown as biofilms. Since EDTA treatment yielded highest protein content, we used this method to isolate ECM for further experiments described in this study.

\section{DIGE Analyses Revealed Differential Expression Of Pro- teins In Cell Walls And ECM During Candida Biofilm Formation In A Phase-Dependent Manner}

A major concern in proteomic studies is variability between different preparations of protein samples. To overcome such potential variability, we performed DIGE analysis of samples obtained from four separate replicates, followed by cluster analyses of the normalized volume of protein spots. Visualization of differentially expressed clusters of protein spots clearly showed that there was minimal variation between the different batches of protein samples (see representative data in Fig. 2).

DIGE-analysis revealed differences in protein profiles of ECM samples isolated from early and mature biofilms compared to planktonic cells (see representative images in Fig. 3). We found that 107 proteins were differentially expressed in biofilm ECM, of which 51 were differentially expressed at early phase, while 56 were differentially expressed at mature phase (Table 1). Among these proteins, 94\% (48/51) and $96 \%(54 / 56)$ were overexpressed in ECM isolated from early $(6 \mathrm{~h})$ and mature $(48 \mathrm{~h})$ phase biofilms, respectively.

Table 1. Number of Differentially Expressed Proteins* in Matrix and Cell Walls of $C$. albicans Biofilms at Early and Mature Phase

\begin{tabular}{|c|c|c|c|c|}
\hline $\begin{array}{c}\text { Protein } \\
\text { Sample }\end{array}$ & $\begin{array}{c}\text { Biofilm } \\
\text { Phase }\end{array}$ & Total & Upregulated & Downregulated \\
\hline \hline \multirow{2}{*}{ Cell walls } & Early & 9 & 6 & 3 \\
\cline { 2 - 5 } & Mature & 35 & 24 & 11 \\
\hline \multirow{2}{*}{ Extracellular } & Early & 51 & 48 & 3 \\
\cline { 2 - 5 } & Mature & 56 & 54 & 2 \\
\hline
\end{tabular}

*with known putative functions.

Similar analysis of cell wall-associated protein samples revealed that 44 proteins were differentially expressed with 9 
and 35 differentially expressed at early and mature phase, respectively (Table 1). Furthermore, among these differentially expressed cell wall proteins, 67\% (6/9) and $68 \%$ $(24 / 35)$ were overexpressed in cell walls isolated from early $(6 \mathrm{~h})$ and mature $(48 \mathrm{~h})$ phase biofilms, respectively. These results clearly showed that $C$. albicans cell walls and ECM fractions induce differential expression of proteins in a phase-dependent manner that was independent of batch-tobatch variation.
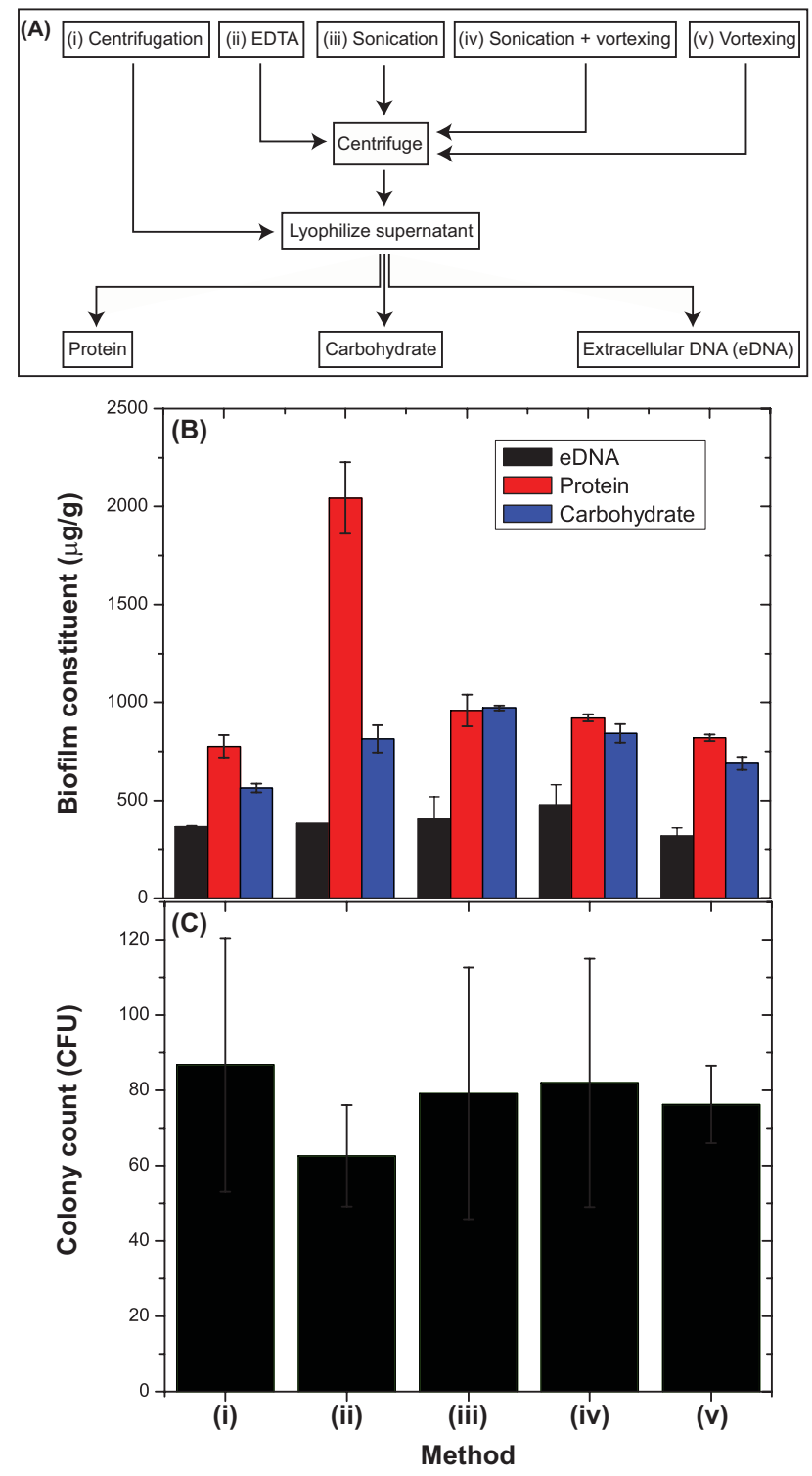

Fig. (1). Isolation of matrix from Candida biofilms. (A) Schema showing the five different methods for isolation of extracellular matrix from C. albicans grown as biofilm or planktonic cells, (B) total carbohydrate, protein, and extracellular DNA (eDNA) yield in matrix isolated using the five different methods, (C) Effect of different isolation methods on cell viability. Sample in Group (i) was centrifuged at $10,000 \mathrm{xg}$ for $30 \mathrm{~min}$ at $4^{\circ} \mathrm{C}$, and the supernatant was collected. Samples in Groups (ii), (iii), (iv), and (v) were treated according to the following methods: (ii) incubation with EDTA (10 $\mathrm{mM}$, for $2 \mathrm{~h}$ at $4^{\circ} \mathrm{C}$ ), (iii) ultrasonication for $10 \mathrm{~min}$, (iv) ultrasonication for $2 \mathrm{~min}$ followed by vortexing for $10 \mathrm{~min}$, and (v) vortexing only, for $10 \mathrm{~min}$.
Mass Spectrometric Identification Revealed Differentially Expressed Proteins in C. albicans Biofilms Associated With Metabolic Processes

Next we used mass spectrometry to determine the identities of the differentially expressed proteins. We found that $51 \%(23 / 51)$ and $50 \%(28 / 56)$ of the differentially expressed ECM proteins were identified as metabolic enzymes in early and mature phase biofilms, respectively. In contrast, all the cell wall-associated differentially expressed proteins in early phase were metabolic enzymes (9/9), while 65\% (23/35) of cell wall proteins differentially expressed in mature phase were identified as metabolism-related enzymes (Fig. 4). Among the metabolism-associated proteins in biofilm matrix, 100\% (23/23) and 96\% (27/28) proteins were overexpressed at early and mature phase, respectively. In contrast, $67 \%(6 / 9)$ and $74 \%(17 / 23)$ of the metabolic proteins in biofilm cell walls were overexpressed.

These studies demonstrated that metabolic pathwayassociated proteins were upregulated in biofilms compared to planktonic cells, and among biofilms between early and mature phases.

\section{Pathway Mapping Analyses Revealed Metabolic Path- ways are Differentially Expressed in Matrix and Cell Walls of Early And Mature C. albicans Biofilms}

To discern the broader pattern of protein expression and the functional patterns operative among the proteins expressed differentially in C. albicans biofilms, we performed pathway mapping of our proteomics data using the online "Omics" pathway analysis tool (http://pathway.yeastgenome. org:8555/expression.html) and the KEGG Pathway Coloring Tool (http://www.genome.jp/kegg/tool/color_pathway .html) [28]. Our analyses revealed that among ECM proteins isolated from biofilms, those involved in carbohydrate metabolism, amino acid biosynthesis, and calcium signaling pathways were overexpressed at both early and mature developmental phases (Fig. 5).

Interestingly, although most pathways were overexpressed at both early and mature phases, the number and/or identity of representative proteins from the pathways differed between early and mature phases. For example, at early phase, the only overexpressed protein involved in glycolysis/gluconeogenesis was glyceraldehyde-3-phosphate dehydrogenase (GAPDH, 9.1 fold) (Tables 2-5). In contrast, at mature phase, we found that three glycolysis/gluconeogenesis-related proteins - GAPDH, phosphoglycerate kinase (PGK), and fructose bisphosphate aldolase (FBP) - were overexpressed by $8.6,11.18$, and 15.6 fold, respectively, in biofilms (see representative image, Figs. 6 and 7). Furthermore, while glutamate and nitrogen metabolism pathways were represented only in early phase biofilms, proteins involved in purine metabolism, glycine/serine/threonine metabolism, carbon fixation, and inositol metabolism were overexpressed only in mature phase biofilms (Table 6). Analysis of cell wall proteins revealed that 17 metabolic pathways were overexpressed in cell walls of early phase biofilms. At mature phase, cell walls of biofilms overexpressed proteins involved in 31 metabolic pathways, including 14 that were overexpressed only in biofilms grown to this phase (Table 6). These 14 mature phase-specific pathways included: citrate cycle (TCA cycle), pentose phosphate 

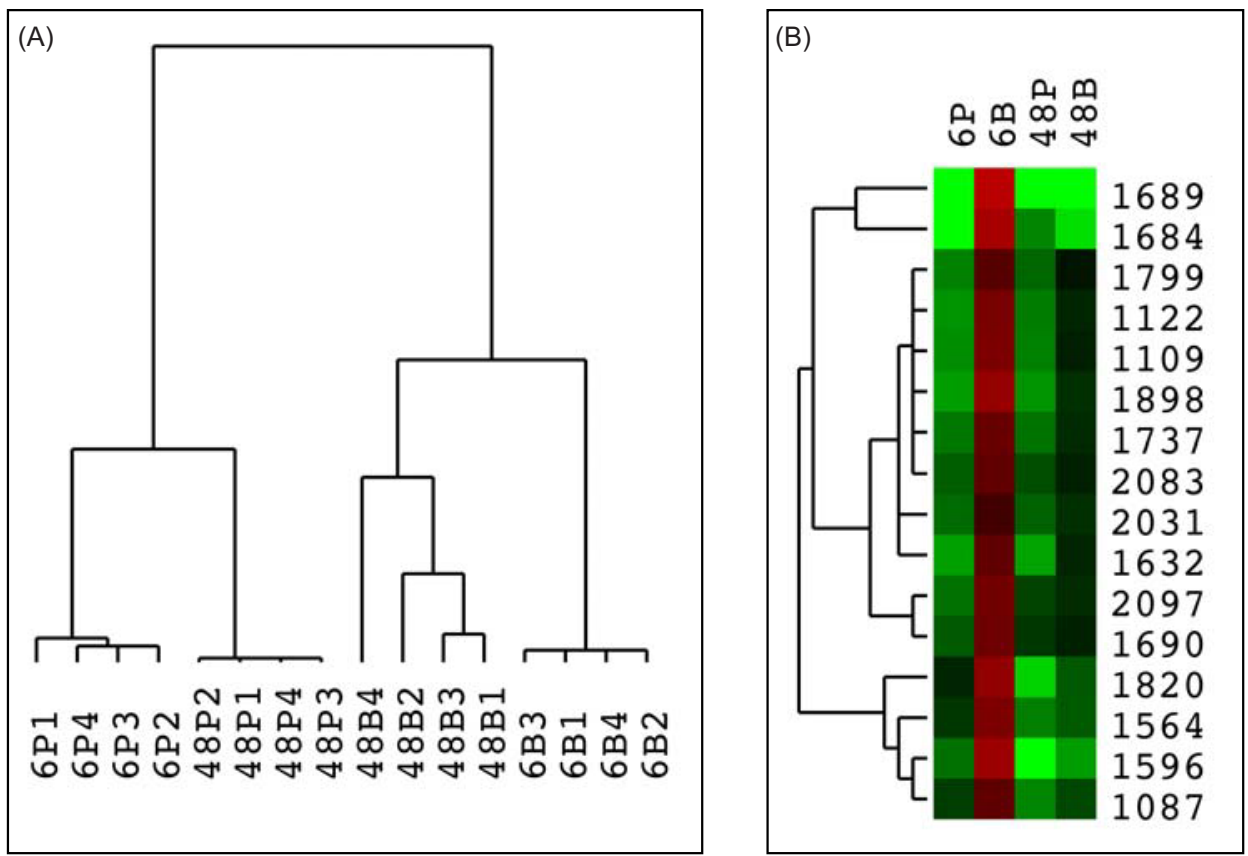

Fig. (2). Cluster analysis with proteins significantly different in matrix isolated from $C$. albicans biofilm compared to planktonic cells, showing (A) overall consistency and (B) changes in average of specific protein spots in each group of gels. Color differences illustrate log-transformed volume of protein spots. Samples from the different experimental groups are indicated on the column labels, and protein spots are displayed on the $\mathrm{y}$-axis. Red color indicates high level expression, green color indicates low expression, and black indicates median expression. 6P: 6 hr Planktonic, 6B: 6hr Biofilm, 48P: 48 hr Planktonic, 48B: 48hr Biofilm.

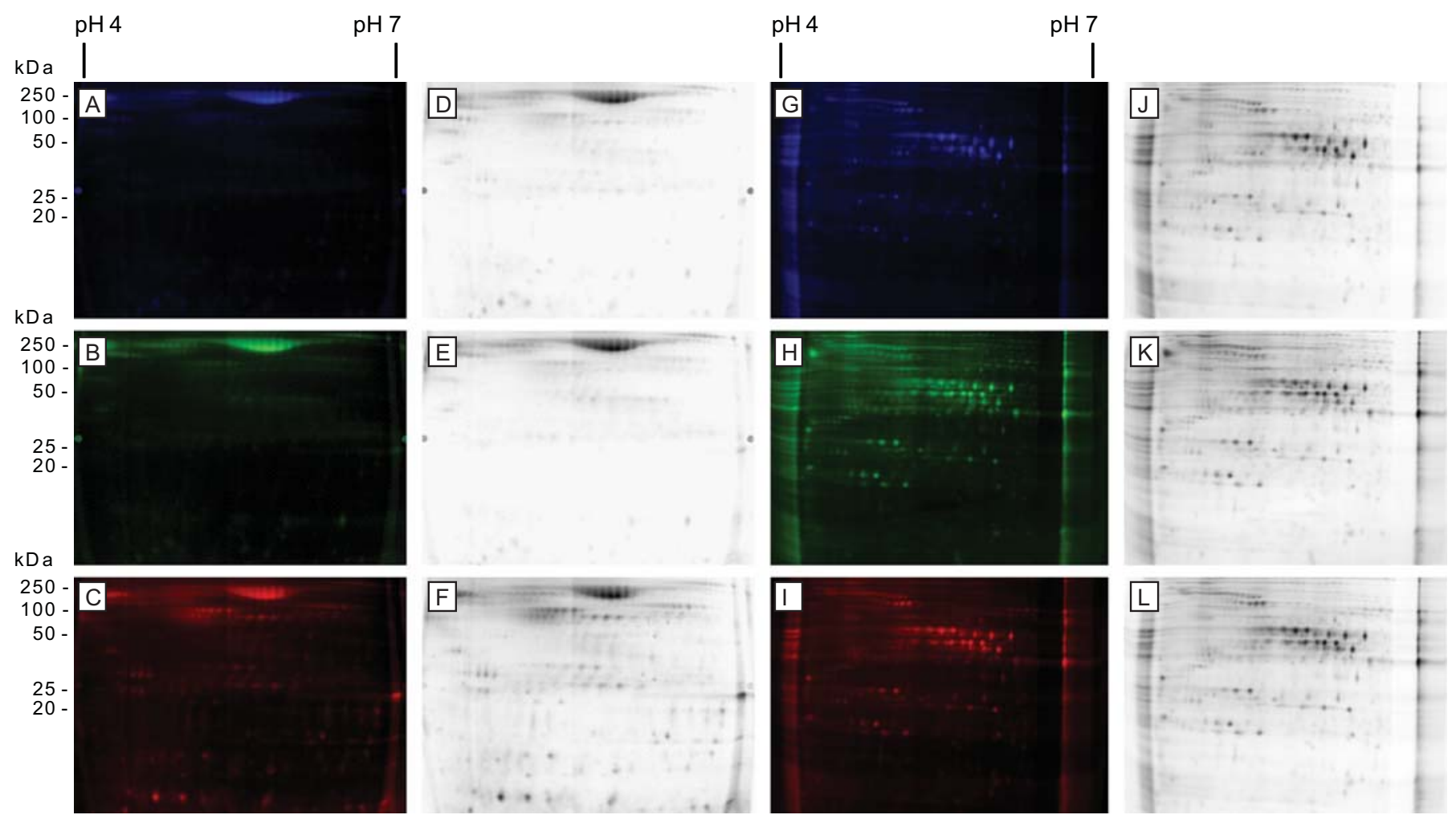

Fig. (3). Two dimensional difference in-gel electrophoresis (2D-DIGE) analyses of extracellular matrix (ECM) proteins isolated from C. albicans grown as biofilm or planktonic cells. Panels A-F: ECM samples, panels G-I: cell wall samples; Fluorescent scan images of gels are shown in panels A-C and G-I, while the corresponding post-stained purple gels are shown in panels D-F and J-L. Protein samples were stained with Cy3 (green), or Cy5 (red). Internal standard samples were stained with Cy2 (blue). Panels A,D,G,J: internal standard; Panels B,E,I,L: biofilm samples, and Panels C,F,H,K: planktonic samples. pI range: $\mathrm{pH} 4-7$, molecular weight range: $20-250 \mathrm{kDa}$, indicated on the left of gel images. 


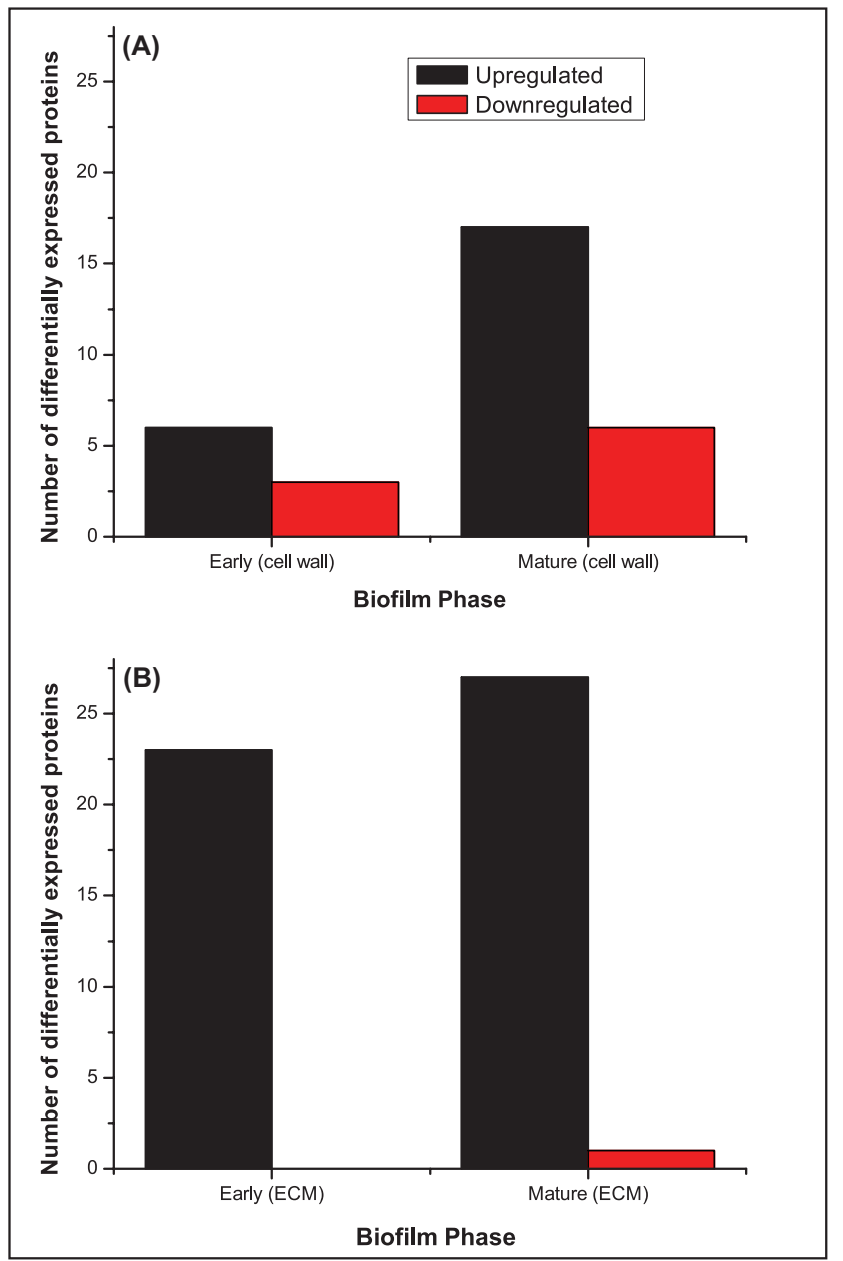

Fig. (4). Differentially expressed metabolic enzymes in (A) cell walls and (B) extracellular matrix (ECM) of $C$. albicans biofilms grown to early or mature phases. Majority of metabolic enzymes were upregulated in biofilms at both developmental phases.

pathway, pyruvate metabolism, amino acid metabolism, alpha-linolenic acid metabolism, polyunsaturated fatty acid biosynthesis, aminoacyl-tRNA biosynthesis, PPAR signaling pathway, and calcium signaling pathway. Phase-dependent differences in the number and identity of pathway associated proteins were also observed among cell wall proteins. In this regard, four glycolytic proteins - alcohol dehydrogenase, enolase, triose phosphate isomerase, and phosphoglycerate mutase were overexpressed in early phase biofilms, while eight glycolytic proteins - alcohol dehydrogenase, glyceraldehyde-3-phosphate dehydrogenase, phosphoglycerate kinase, pyruvate decarboxylase, fructose-bisphosphate aldolase, phosphopyruvate hydratase, enolase, triose-phosphate isomerase, and phosphoglycerate mutase were overexpressed at mature phase (Table 4). When comparing the levels of ADH1 between the two phases of biofilms (early vs. mature), we found the levels of Adh1p decreased by 1.59 fold, in agreement with our previously published study which showed that Adh1p level is decreased in mature biofilms. Taken together, these analyses revealed that metabolic pathways (especially glycolysis/gluconeogenesis) were differentially expressed in matrix and cell walls of early and mature C. albicans biofilms.

\section{The GAPDH Inhibitor Sodium Iodoacetate Inhibits Biofilm Formation}

Since glycolysis was one of the metabolic pathways that was overexpressed in both matrix and cell walls isolated from early and nature C. albicans biofilms, and GAPDH was the most highly overexpressed glycolytic enzyme at both developmental phases, we hypothesized that inhibition of this enzyme will attenuate the ability of $C$. albicans to form biofilms. To test this hypothesis, we determined the effect of sodium iodoacetate, which specifically and irreversibly inhibits GAPDH [29], on the ability of C. albicans to form biofilms. As shown in Fig. (8), the ability of $C$. albicans to form early and mature phase biofilms was significantly reduced in the presence of this inhibitor, as measured by dry weight determination (Fig. 8A-B; P $\leq 0.001$ for both).

Similar effect of sodium iodoacetate was observed on the metabolic activity (determined by XTT assay) of $C$. albicans biofilms (data not shown). Next, we used confocal microscopy to determine the effect of sodium iodoacetate on the morphology and architecture of $C$. albicans biofilms. We found that $C$. albicans, when exposed to sodium iodoacetate, grew only as sparse, adherent blastospores and did not form robust biofilms (Fig. 8D). As expected, in absence of sodium iodoacetate, $C$. albicans formed typical, hyphae-rich biofilms (Fig. 8C). These results clearly demonstrated that glycolytic pathway, and specifically GAPDH, plays a critical role in biofilm formation.

\section{DISCUSSION AND CONCLUSIONS}

In this study, we performed proteomic analyses of ECM and cell wall proteins isolated from $C$. albicans biofilms and demonstrated that the protein profiles in these two compartment of biofilms expressed differential levels of proteins in a phase-dependent manner. Additionally, we mapped these differentially expressed proteins to cellular pathways and identified metabolic pathways that are differentially expressed in Candida biofilm. These results demonstrate the value of pathway mapping in interpreting the "omic" data on biofilms.

To identify the optimal method for isolation of biofilm matrix, we compared the protein, DNA, and carbohydrate yield in matrix isolated from $C$. albicans biofilms using five different methods - centrifugation, EDTA-treatment, ultrasonication with or without vortexing, and vortexing alone. Our studies revealed that the protein content was significantly higher in matrix isolated using EDTA extraction than in samples isolated using the other four methods tested. In a previous study, investigators reported using ultrasonication to isolate Candida biofilm matrix $[15,34]$ and treatment with beta-mercaptoethanol to isolate cell surface components [15]. Previously, Zhang et al. [35] compared similar methods to extract extracellular polymeric substances (EPS) from biofilms formed by bacteria, and showed that EDTA-based method was the most efficient. Since our goal in the current study was to evaluate the protein profile of biofilm matrix and cell walls, we used the EDTA-based method to isolate extracellular matrix from biofilms and planktonic cells. The higher yield of EDTA method renders it especially suitable for investigating subtle protein-protein interactions involving low-yield proteins in the biofilm matrix. In this regard, our 


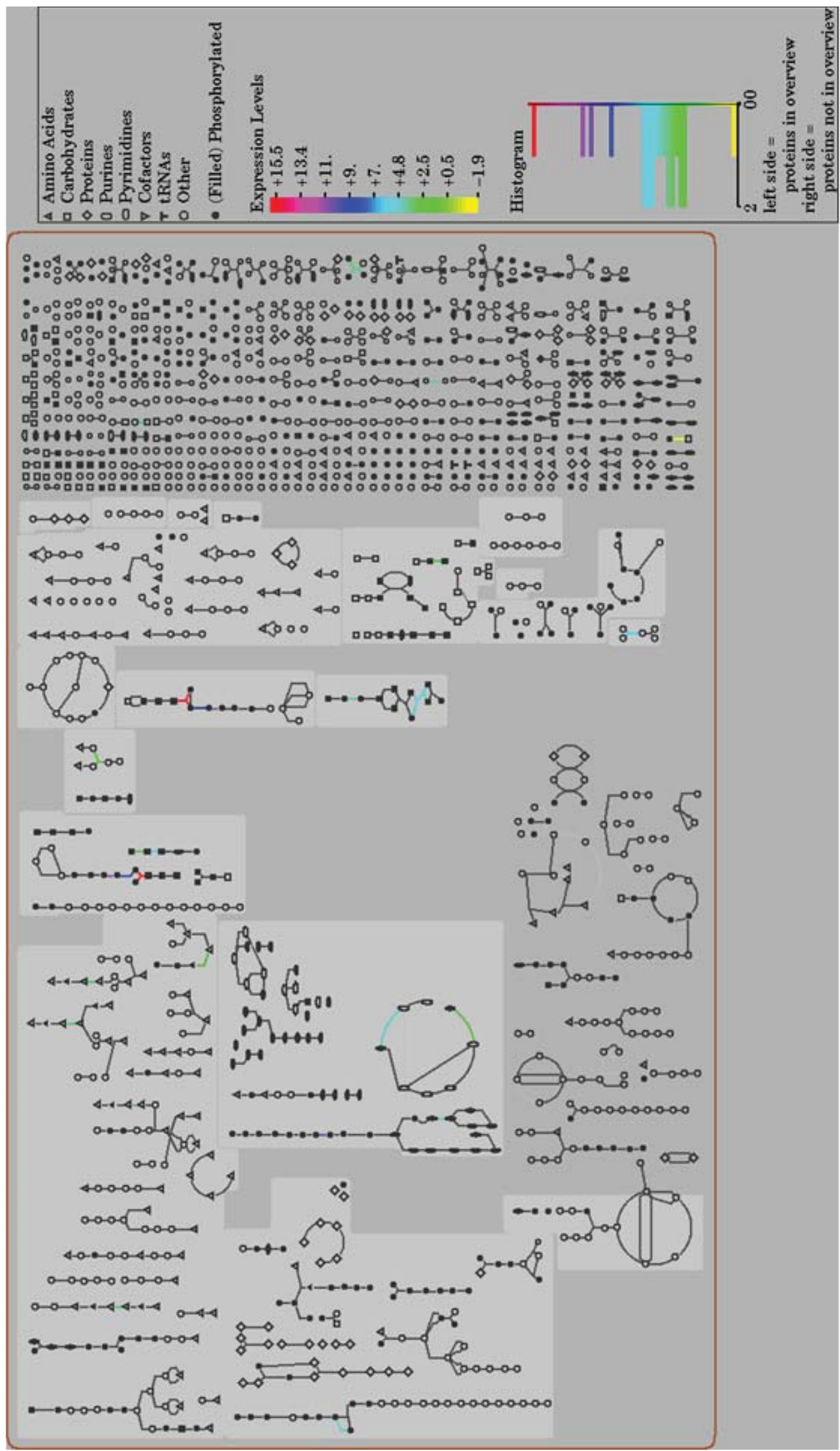

Fig. (5). Pathway mapping of matrix proteins isolated from mature phase $\boldsymbol{C}$. albicans biofilms. This diagram provides a schematic of all pathways of $S$. cerevisiae metabolism in the yeast genome database available online at http://www.yeastgenome.org/. Nodes represent metabolites, with shape indicating class of metabolite (see key); lines represent reactions. Differentially expressed pathways are indicated in color. Analysis was based on comparison with the online yeast genome database using S. cerevisiae S288C as the comparator. 


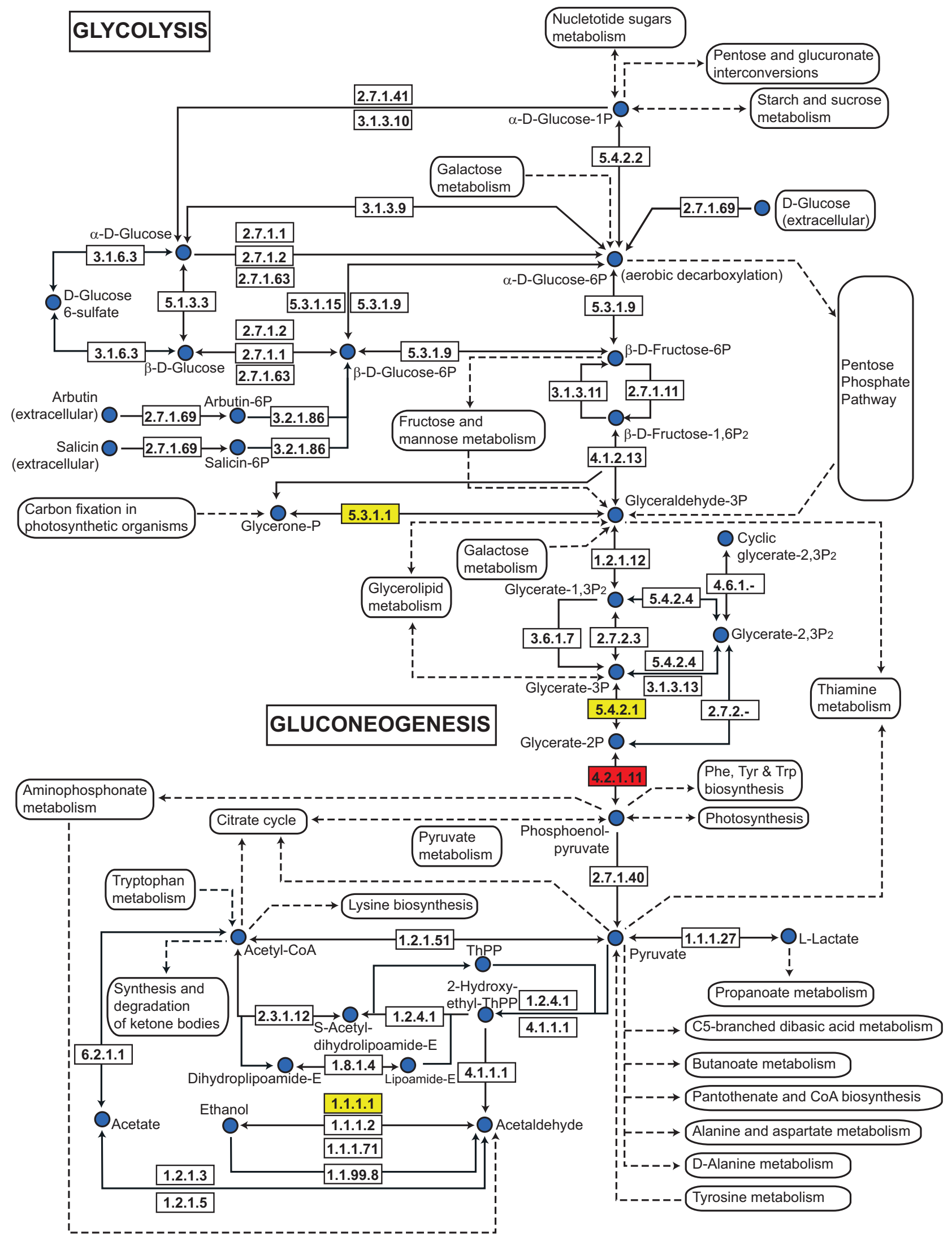

Fig. (6). Representative image showing differentially expressed proteins in the glycolysis/gluconeogenesis pathways in early phase $C$. albicans biofilms. The KEGG Pathway coloring tool was used to identify enzymes whose levels in biofilms were upregulated (yellow) or downregulated (red). 


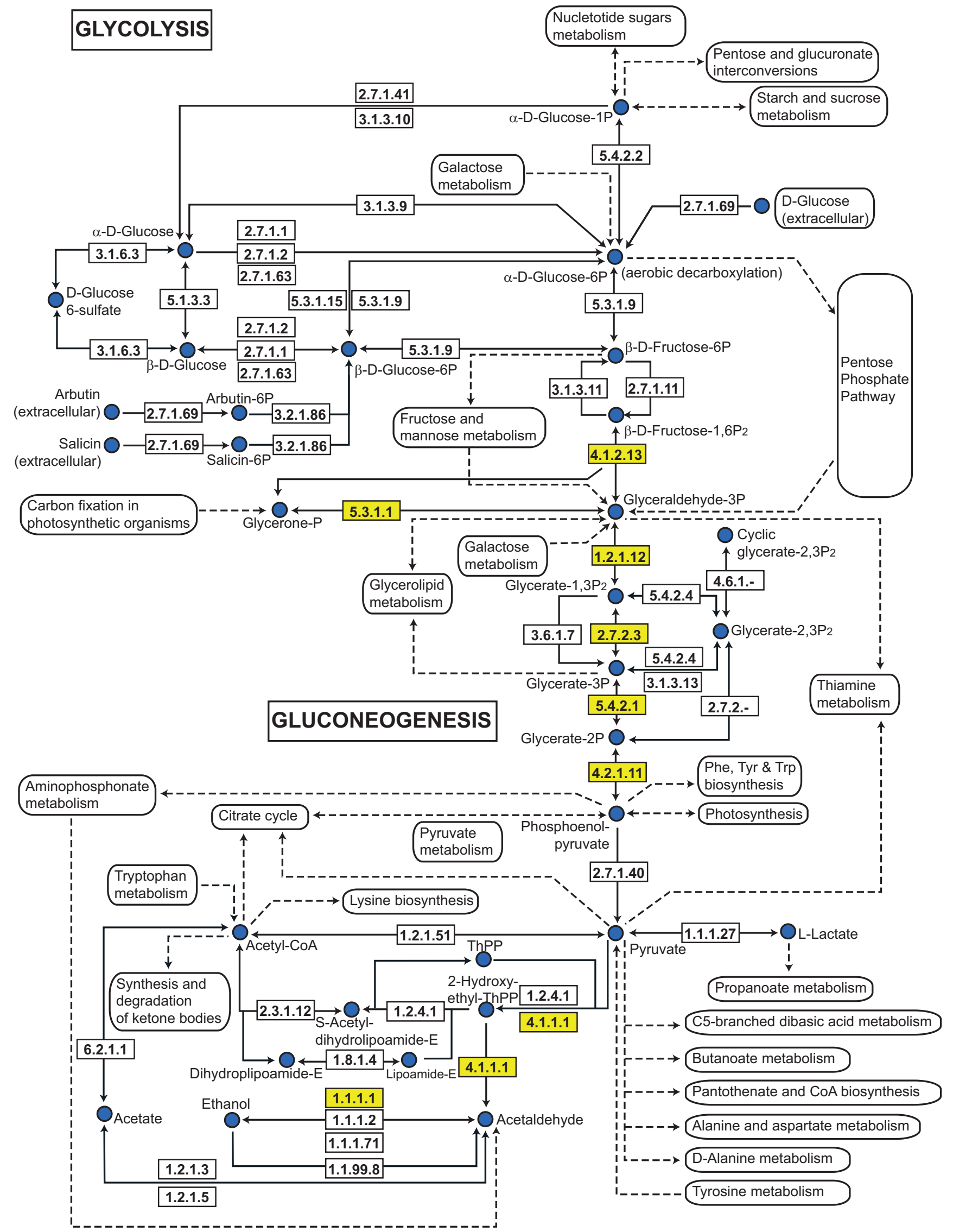

Fig. (7). Representative image showing differentially expressed proteins in the glycolysis/gluconeogenesis pathways in mature phase C. albicans biofilms. The KEGG Pathway coloring tool was used to identify differentially expressed enzymes in biofilms. Yellow boxes upregulated enzymes, red boxes - downregulated enzymes. 
Table 2. Differentially Expressed Proteins in Matrix Isolated from C. albicans Biofilms Grown to Early Phase and Planktonic Cells Grown to the Same Time Point

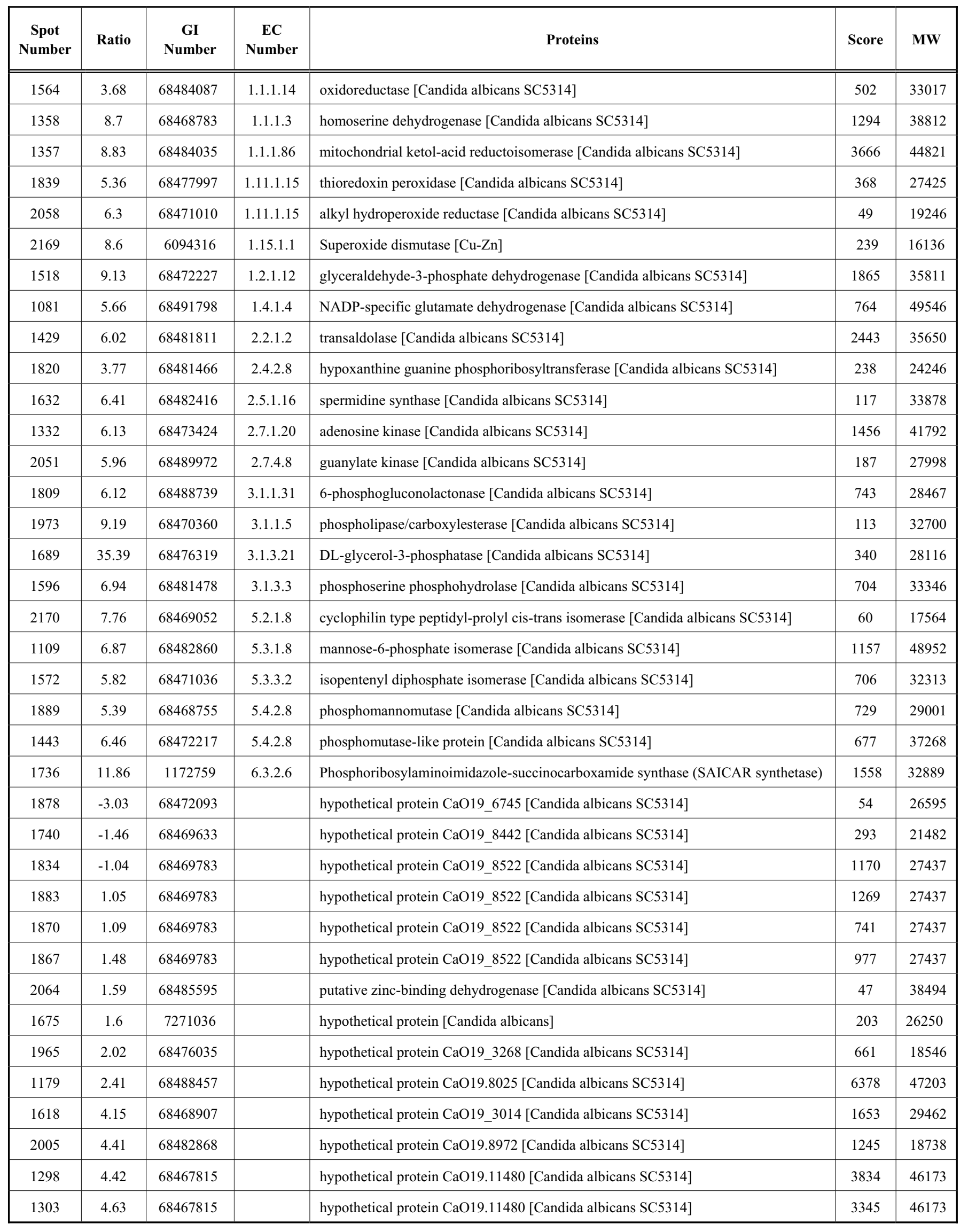


(Table 2) contd....

\begin{tabular}{|c|c|c|c|c|c|c|}
\hline $\begin{array}{c}\text { Spot } \\
\text { Number }\end{array}$ & Ratio & $\begin{array}{c}\text { GI } \\
\text { Number }\end{array}$ & $\begin{array}{c}\text { EC } \\
\text { Number }\end{array}$ & Proteins & Score & MW \\
\hline 1627 & 4.68 & 68468907 & & hypothetical protein CaO19_3014 [Candida albicans SC5314] & 1149 & 29462 \\
\hline 1980 & 5.21 & 68466605 & & putative salvage phosphoribosyl transferase [Candida albicans SC5314] & 367 & 20864 \\
\hline 1187 & 5.27 & 68471189 & & hypothetical protein $\mathrm{CaO} 19.7080$ [Candida albicans SC5314] & 1497 & 40061 \\
\hline 1223 & 5.51 & 68475061 & & putative translation initiation factor eIF4A subunit [Candida albicans SC5314] & 1291 & 44571 \\
\hline 1724 & 5.82 & 68481819 & & hypothetical protein $\mathrm{CaO} 19.4375$ [Candida albicans SC5314] & 223 & 30410 \\
\hline 1784 & 6.64 & 68475757 & & hypothetical protein CaO19_5749 [Candida albicans SC5314] & 359 & 23899 \\
\hline 1778 & 7.13 & 68475892 & & hypothetical protein CaO19_13172 [Candida albicans SC5314] & 505 & 23856 \\
\hline 1424 & 8.79 & 68467815 & & hypothetical protein $\mathrm{CaO} 19.11480$ [Candida albicans SC5314] & 1430 & 46173 \\
\hline 1898 & 9.31 & 68488079 & & putative ubiquitin-conjugating enzyme $\mathrm{Ubc} 1 \mathrm{p}$ & 435 & 25441 \\
\hline 2104 & 11.83 & 68482868 & & hypothetical protein $\mathrm{CaO} 19.8972$ [Candida albicans SC5314] & 350 & 18738 \\
\hline 1816 & 12 & 68469783 & & hypothetical protein CaO19_8522 [Candida albicans SC5314] & 284 & 27437 \\
\hline
\end{tabular}

Table 3. Differentially Expressed Proteins in Matrix Isolated from C. albicans Biofilms Grown to Mature Phase and Planktonic Cells Grown to the Same Time Point

\begin{tabular}{|c|c|c|c|c|c|c|}
\hline $\begin{array}{c}\text { Spot } \\
\text { Number }\end{array}$ & Ratio & $\begin{array}{l}\text { GI Num- } \\
\text { ber }\end{array}$ & $\begin{array}{c}\text { EC } \\
\text { Number }\end{array}$ & Proteins & Score & MW \\
\hline 1447 & 3.17 & 68470480 & 1.1 .1 .14 & oxidoreductase [Candida albicans SC5314] & 457 & 37611 \\
\hline 1312 & 3 & 68468783 & 1.1.1.3 & homoserine dehydrogenase [Candida albicans SC5314] & 740 & 38812 \\
\hline 1358 & 3.15 & 68468783 & 1.1 .1 .3 & homoserine dehydrogenase [Candida albicans SC5314] & 1294 & 38812 \\
\hline 1357 & 7.71 & 68484035 & 1.1 .1 .86 & mitochondrial ketol-acid reductoisomerase [Candida albicans SC5314] & 3666 & 44821 \\
\hline 1343 & 9.92 & 68484035 & 1.1.1.86 & mitochondrial ketol-acid reductoisomerase [Candida albicans SC5314] & 531 & 44821 \\
\hline 1839 & 5.46 & 68477997 & 1.11 .1 .15 & thioredoxin peroxidase [Candida albicans SC5314] & 368 & 27425 \\
\hline 2058 & 8.14 & 68471010 & 1.11 .1 .15 & alkyl hydroperoxide reductase [Candida albicans SC5314] & 49 & 19246 \\
\hline 2023 & 10.39 & 68477997 & 1.11 .1 .15 & thioredoxin peroxidase [Candida albicans SC5314] & 135 & 27425 \\
\hline 2169 & 5.77 & 6094316 & 1.15 .1 .1 & Superoxide dismutase $[\mathrm{Cu}-\mathrm{Zn}]$ & 239 & 16136 \\
\hline 1518 & 8.6 & 68472227 & 1.2 .1 .12 & glyceraldehyde-3-phosphate dehydrogenase [Candida albicans SC5314] & 1865 & 35811 \\
\hline 1429 & 5.31 & 68481811 & 2.2.1.2 & transaldolase [Candida albicans SC5314] & 2443 & 35650 \\
\hline 1820 & 2.41 & 68481466 & 2.4.2.8 & hypoxanthine guanine phosphoribosyltransferase [Candida albicans SC5314] & 238 & 24246 \\
\hline 1632 & 2.51 & 68482416 & 2.5 .1 .16 & spermidine synthase [Candida albicans SC5314] & 117 & 33878 \\
\hline 1332 & 3.75 & 68473424 & 2.7.1.20 & adenosine kinase [Candida albicans SC5314] & 1456 & 41792 \\
\hline 1330 & 4.79 & 68473424 & 2.7 .1 .20 & adenosine kinase [Candida albicans SC5314] & 1920 & 41792 \\
\hline 1242 & 11.18 & 68489602 & 2.7 .2 .3 & 3-phosphoglycerate kinase [Candida albicans SC5314] & 2484 & 45152 \\
\hline 2051 & 5.54 & 68489972 & 2.7.4.8 & guanylate kinase [Candida albicans SC5314] & 187 & 27998 \\
\hline 1809 & 3.82 & 68488739 & 3.1 .1 .31 & 6-phosphogluconolactonase [Candida albicans SC5314] & 743 & 28467 \\
\hline 1973 & 3.78 & 68470360 & 3.1 .1 .5 & phospholipase/carboxylesterase [Candida albicans SC5314] & 113 & 32700 \\
\hline
\end{tabular}


(Table 3) contd....

\begin{tabular}{|c|c|c|c|c|c|c|}
\hline 1684 & -1.9 & 68476319 & 3.1.3.21 & DL-glycerol-3-phosphatase [Candida albicans SC5314] & 284 & 28116 \\
\hline 1596 & 2.03 & 68481478 & 3.1.3.3 & phosphoserine phosphohydrolase [Candida albicans SC5314] & 704 & 33346 \\
\hline 1380 & 15.6 & 68466123 & 4.1.2.13 & fructose-bisphosphate aldolase [Candida albicans SC5314] & 1657 & 39191 \\
\hline 1109 & 2.03 & 68482860 & 5.3.1.8 & mannose-6-phosphate isomerase [Candida albicans SC5314] & 1157 & 48952 \\
\hline 1572 & 5.09 & 68471036 & 5.3.3.2 & isopentenyl diphosphate isomerase [Candida albicans SC5314] & 706 & 32313 \\
\hline 1889 & 5.18 & 68468755 & 5.4.2.8 & phosphomannomutase [Candida albicans SC5314] & 729 & 29001 \\
\hline 1443 & 5.65 & 68472217 & 5.4.2.8 & phosphomutase-like protein [Candida albicans SC5314] & 677 & 37268 \\
\hline 1965 & 1.69 & 68476035 & & hypothetical protein CaO19_3268 [Candida albicans SC5314] & 661 & 18546 \\
\hline 1980 & 1.91 & 68466605 & & putative salvage phosphoribosyl transferase [Candida albicans SC5314] & 367 & 20864 \\
\hline 1898 & 2.09 & 68488079 & & putative ubiquitin-conjugating enzyme Ubc1p [Candida albicans SC5314] & 435 & 25441 \\
\hline 1834 & 2.4 & 68469783 & & hypothetical protein CaO19_8522 [Candida albicans SC5314] & 1170 & 27437 \\
\hline 1223 & 2.52 & 68475061 & & putative translation initiation factor eIF4A subunit [Candida albicans SC5314] & 1291 & 44571 \\
\hline 2005 & 3.02 & 68482868 & & hypothetical protein $\mathrm{CaO} 19.8972$ [Candida albicans SC5314] & 1245 & 18738 \\
\hline 1778 & 3.4 & 68475892 & & hypothetical protein $\mathrm{CaO} 19 \_13172$ [Candida albicans SC5314] & 505 & 23856 \\
\hline 1724 & 3.68 & 68481819 & & hypothetical protein $\mathrm{CaO} 19.4375$ [Candida albicans SC5314] & 223 & 30410 \\
\hline 1424 & 5.68 & 68467815 & & hypothetical protein CaO19.11480 [Candida albicans SC5314] & 1430 & 46173 \\
\hline 1816 & 8.09 & 68469783 & & hypothetical protein CaO19_8522 [Candida albicans SC5314] & 284 & 27437 \\
\hline 1675 & 8.93 & 7271036 & & hypothetical protein [Candida albicans] & 203 & 26250 \\
\hline 2064 & 8.97 & 68485595 & & putative zinc-binding dehydrogenase [Candida albicans SC5314] & 47 & 38494 \\
\hline 1179 & 9.25 & 68488457 & & hypothetical protein $\mathrm{CaO} 19.8025$ [Candida albicans SC5314] & 6378 & 47203 \\
\hline 1618 & 9.53 & 68468907 & & hypothetical protein CaO19_3014 [Candida albicans SC5314] & 1653 & 29462 \\
\hline 1870 & 9.64 & 68469783 & & hypothetical protein $\mathrm{CaO} 19 \_8522$ [Candida albicans SC5314] & 741 & 27437 \\
\hline 1298 & 10.04 & 68467815 & & hypothetical protein $\mathrm{CaO} 19.11480$ [Candida albicans SC5314] & 3834 & 46173 \\
\hline 1627 & 10.28 & 68468907 & & hypothetical protein $\mathrm{CaO} 19$ _3014 [Candida albicans SC5314] & 1149 & 29462 \\
\hline 1303 & 11.17 & 68467815 & & hypothetical protein $\mathrm{CaO} 19.11480$ [Candida albicans SC5314] & 3345 & 46173 \\
\hline 1878 & 11.34 & 68472093 & & hypothetical protein CaO19_6745 [Candida albicans SC5314] & 54 & 26595 \\
\hline 1740 & 13.27 & 68469633 & & hypothetical protein $\mathrm{CaO} 19 \_8442$ [Candida albicans SC5314] & 293 & 21482 \\
\hline 1883 & 13.54 & 68469783 & & hypothetical protein CaO19_8522 [Candida albicans SC5314] & 1269 & 27437 \\
\hline 1867 & 20.39 & 68469783 & & hypothetical protein CaO19_8522 [Candida albicans SC5314] & 977 & 27437 \\
\hline
\end{tabular}


Table 4. Differentially Expressed Proteins in Cell Walls Isolated from C. albicans Biofilms Grown to Early Phase and Planktonic Cells Grown to the Same Time Point

\begin{tabular}{|c|c|c|c|c|c|c|c|c|}
\hline $\begin{array}{l}\text { Spot } \\
\text { No. }\end{array}$ & $\begin{array}{c}\text { Average } \\
\text { Ratio* }\end{array}$ & $\begin{array}{l}\text { P - Spot } \\
\text { Vol. }\end{array}$ & Accession & Protein & $\begin{array}{c}\text { Protein } \\
\text { Probability }\end{array}$ & Coverage & pI & $\begin{array}{l}\text { Molecular } \\
\text { Weight }\end{array}$ \\
\hline & & & 68479353 & $\begin{array}{l}\text { gi|68479353|ref|XP_716208.1| hypothetical protein CaO19_6367 [Candida albicans } \\
\text { SC5314] }\end{array}$ & $1.60 \mathrm{E}-11$ & 17.8 & 5.1 & 66408.6 \\
\hline & & & 607055 & gi|607055|emb|CAA82929.1| heat shock protein 70 [Candida albicans] & $1.50 \mathrm{E}-10$ & 23.2 & 4.9 & 70281.2 \\
\hline \multirow[t]{3}{*}{219} & -1.8 & 3019435 & 68485837 & $\begin{array}{l}\text { gi|68485837|ref|XP_713199.1| mitochondrial import protein [Candida albicans } \\
\text { SC5314] }\end{array}$ & $1.87 \mathrm{E}-09$ & 22.1 & 5.3 & 69705.5 \\
\hline & & & 68485837 & $\begin{array}{l}\text { gi|68485837|ref|XP_713199.1| mitochondrial import protein [Candida albicans } \\
\text { SC5314] }\end{array}$ & $1.20 \mathrm{E}-10$ & 29.5 & 5.3 & 69705.5 \\
\hline & & & 68468638 & $\begin{array}{l}\text { gi|68468638|ref|XP_721638.1| putative vacuolar ATPase V1 complex subunit A } \\
\text { [Candida albicans SC5314] }\end{array}$ & $1.83 \mathrm{E}-09$ & 19.4 & 5.1 & 63250 \\
\hline \multirow[t]{2}{*}{233} & -1.73 & 4619734 & 607055 & gi|607055|emb|CAA82929.1| heat shock protein 70 [Candida albicans] & $2.15 \mathrm{E}-09$ & 29.3 & 4.9 & 70281.2 \\
\hline & & & 68479353 & $\begin{array}{l}\text { gi|68479353|ref|XP_716208.1| hypothetical protein CaO19_6367 [Candida albicans } \\
\text { SC5314] }\end{array}$ & $3.33 \mathrm{E}-15$ & 29.4 & 5.1 & 66408.6 \\
\hline 287 & -1.07 & 8757535 & 68485837 & $\begin{array}{l}\text { gi|68485837|ref|XP_713199.1| mitochondrial import protein [Candida albicans } \\
\text { SC5314] }\end{array}$ & $6.35 \mathrm{E}-11$ & 21.5 & 5.3 & 69705.5 \\
\hline 315 & -1.2 & 689448 & 68468218 & $\begin{array}{l}\text { gi|68468218|ref|XP_721948.1| dihydroxyacid dehydratase [Candida albicans } \\
\text { SC5314] }\end{array}$ & $5.78 \mathrm{E}-12$ & 20.7 & 6.2 & 62824.9 \\
\hline \multirow[t]{2}{*}{329} & -1.26 & 2738890 & 68485963 & gi|68485963|ref|XP_713100.1| heat shock protein 60 [Candida albicans SC5314] & $1.76 \mathrm{E}-12$ & 39.6 & 5.1 & 60088.7 \\
\hline & & & 68485963 & gi|68485963|ref|XP_713100.1| heat shock protein 60 [Candida albicans SC5314] & $1.30 \mathrm{E}-11$ & 32.2 & 5.1 & 60088.7 \\
\hline 338 & -1.21 & 1946380 & 68477333 & $\begin{array}{l}\text { gi|68477333|ref|XP_717293.1| hypothetical protein CaO19_11293 [Candida albicans } \\
\text { SC5314] }\end{array}$ & $6.69 \mathrm{E}-08$ & 13.9 & 4.6 & 58494.5 \\
\hline 348 & -1.19 & 15085306 & 68480872 & gi|68480872|ref|XP_715589.1| pyruvate decarboxylase [Candida albicans SC5314] & $5.68 \mathrm{E}-13$ & 37.4 & 5.3 & 62402 \\
\hline 382 & 1.12 & 3956254 & 68480872 & gi|68480872|ref|XP_715589.1| pyruvate decarboxylase [Candida albicans SC5314] & $3.82 \mathrm{E}-12$ & 30.3 & 5.3 & 62402 \\
\hline 405 & -1.22 & 10257758 & 68480872 & gi|68480872|ref|XP_715589.1| pyruvate decarboxylase [Candida albicans SC5314] & $1.47 \mathrm{E}-12$ & 39.2 & 5.3 & 62402 \\
\hline 407 & -1.08 & 11359439 & 68480872 & gi|68480872|ref|XP_715589.1| pyruvate decarboxylase [Candida albicans SC5314] & $6.44 \mathrm{E}-12$ & 35.8 & 5.3 & 62402 \\
\hline \multirow[t]{2}{*}{410} & -1.07 & 8195618 & 68480872 & gi|68480872|ref|XP_715589.1| pyruvate decarboxylase [Candida albicans SC5314] & $4.31 \mathrm{E}-13$ & 45.1 & 5.3 & 62402 \\
\hline & & & 68480872 & gi|68480872|ref|XP_715589.1| pyruvate decarboxylase [Candida albicans SC5314] & $2.27 \mathrm{E}-11$ & 36.9 & 5.3 & 62402 \\
\hline 459 & -1.51 & 2993086 & 68472545 & $\begin{array}{l}\text { gi|68472545|ref|XP_719591.1| hypothetical protein CaO19_9565 [Candida albicans } \\
\text { SC5314] }\end{array}$ & $2.86 \mathrm{E}-09$ & 17.9 & 5.2 & 50275.4 \\
\hline \multirow[t]{2}{*}{520} & 1.02 & 196838 & 68480872 & gi|68480872|ref|XP_715589.1| pyruvate decarboxylase [Candida albicans SC5314] & 7.37E-12 & 22.6 & 5.3 & 62402 \\
\hline & & & 68487498 & $\begin{array}{l}\text { gi|68487498|ref|XP_712370.1| putative mitochondrial matrix dihydrolipoamide } \\
\text { dehydrogenase Lpd1p [Candida albicans SC5314] }\end{array}$ & $2.23 \mathrm{E}-10$ & 24.2 & 6.4 & 52823.8 \\
\hline \multirow[t]{2}{*}{584} & 1 & 2185488 & 68465104 & $\begin{array}{l}\text { gi|68465104|ref|XP_723251.1| putative glucose-6-phosphate dehydrogenase [Can- } \\
\text { dida albicans SC5314] }\end{array}$ & $2.09 \mathrm{E}-08$ & 10.7 & 6.2 & 58253.1 \\
\hline & & & 68488457 & $\begin{array}{l}\text { gi|68488457|ref|XP_711912.1| hypothetical protein CaO19.8025 [Candida albicans } \\
\text { SC5314] }\end{array}$ & $8.24 \mathrm{E}-13$ & 26.6 & 5.4 & 47202.6 \\
\hline 659 & -2.31 & 1196912 & 68479882 & $\begin{array}{l}\text { gi|68479882|ref|XP_716109.1| saccharopine dehydrogenase [Candida albicans } \\
\text { SC5314] }\end{array}$ & $1.51 \mathrm{E}-10$ & 28.8 & 5.3 & 49185.6 \\
\hline 744 & 1.1 & 1026949 & 68467359 & $\begin{array}{l}\text { gi|68467359|ref|XP_722341.1| hypothetical protein CaO19_12491 [Candida albicans } \\
\text { SC5314] } \\
\text { similar to gi|2309076|dbj|BAA21690.1| 6-phosphogluconate dehydrogenase } \\
\text { [Candida albicans] }\end{array}$ & $3.26 \mathrm{E}-10$ & 18.6 & 6.1 & 56874.2 \\
\hline 881 & -1.13 & 7305742 & 68489602 & $\begin{array}{l}\text { gi|68489602|ref|XP_711371.1| 3-phosphoglycerate kinase [Candida albicans } \\
\text { SC5314] }\end{array}$ & $1.32 \mathrm{E}-11$ & 30.2 & 6.1 & 45151.8 \\
\hline \multirow[t]{2}{*}{923} & -2.83 & 10252634 & 68467815 & $\begin{array}{l}\text { gi|68467815|ref|XP_722066.1| hypothetical protein CaO19.11480 [Candida albicans } \\
\text { SC5314] } \\
\text { similar to gi|608690|emb|CAA57342.1| alcohol dehydrogenase [Candida albicans] }\end{array}$ & $4.73 \mathrm{E}-11$ & 48 & 8.2 & 46172.7 \\
\hline & & & 608690 & gi|608690|emb|CAA57342.1| alcohol dehydrogenase [Candida albicans] & $7.81 \mathrm{E}-12$ & 37.7 & 6 & 36856 \\
\hline 954 & -1.23 & 5423859 & 68475148 & $\begin{array}{l}\text { gi|68475148|ref|XP_718292.1| homoisocitrate dehydrogenase [Candida albicans } \\
\text { SC5314] }\end{array}$ & $5.56 \mathrm{E}-11$ & 27.7 & 5.5 & 40643.1 \\
\hline 1021 & 1.61 & 4255656 & 68484035 & $\begin{array}{l}\text { gi|68484035|ref|XP_714020.1| putative mitochondrial ketol-acid reductoisomerase } \\
\text { [Candida albicans SC5314] }\end{array}$ & $2.42 \mathrm{E}-12$ & 42.8 & 6.2 & 44820.5 \\
\hline 1029 & 1.32 & 7946847 & 68484035 & $\begin{array}{l}\text { gi|68484035|ref|XP_714020.1| putative mitochondrial ketol-acid reductoisomerase } \\
\text { [Candida albicans SC5314] }\end{array}$ & $1.31 \mathrm{E}-10$ & 33 & 6.2 & 44820.5 \\
\hline
\end{tabular}


(Table 4) contd...

\begin{tabular}{|c|c|c|c|c|c|c|c|c|}
\hline $\begin{array}{l}\text { Spot } \\
\text { No. }\end{array}$ & $\begin{array}{c}\text { Average } \\
\text { Ratio* }\end{array}$ & $\begin{array}{l}\text { P - Spot } \\
\text { Vol. }\end{array}$ & Accession & Protein & $\begin{array}{c}\text { Protein } \\
\text { Probability }\end{array}$ & Coverage & pI & $\begin{array}{l}\text { Molecular } \\
\text { Weight }\end{array}$ \\
\hline \multirow[t]{2}{*}{1034} & 1.01 & 7790567 & 68484035 & $\begin{array}{l}\text { gi|68484035|ref|XP_714020.1| putative mitochondrial ketol-acid reductoisomerase } \\
\text { [Candida albicans SC5314] }\end{array}$ & $4.63 \mathrm{E}-10$ & 29.8 & 6.2 & 44820.5 \\
\hline & & & 68472462 & $\begin{array}{l}\text { gi|68472462|ref|XP_719792.1| glyceraldehyde-3-phosphate dehydrogenase [Candida } \\
\text { albicans SC5314] }\end{array}$ & $2.04 \mathrm{E}-08$ & 14.6 & 6.7 & 35810.7 \\
\hline 1058 & 1.12 & 1366267 & 68489602 & $\begin{array}{l}\text { gi|68489602|ref|XP_711371.1| 3-phosphoglycerate kinase [Candida albicans } \\
\text { SC5314] }\end{array}$ & $2.81 \mathrm{E}-08$ & 19.4 & 6.1 & 45151.8 \\
\hline \multirow[t]{2}{*}{1060} & -1.63 & 6537573 & 68481267 & $\begin{array}{l}\text { gi|68481267|ref|XP_715408.1| putative anthranilate phosphoribosyl transferase } \\
\text { [Candida albicans SC5314] }\end{array}$ & $1.04 \mathrm{E}-09$ & 18.7 & 5.7 & 39456.6 \\
\hline & & & 68466123 & $\begin{array}{l}\text { gi|68466123|ref|XP_722836.1| fructose-bisphosphate aldolase [Candida albicans } \\
\text { SC5314] }\end{array}$ & $4.79 \mathrm{E}-12$ & 27.3 & 5.7 & 39190.8 \\
\hline 1335 & 1.42 & 2172392 & 68476319 & $\begin{array}{l}\text { gi|68476319|ref|XP_717809.1| putative DL-glycerol-3-phosphatase [Candida albi- } \\
\text { cans SC5314] }\end{array}$ & $2.48 \mathrm{E}-10$ & 22 & 5.4 & 28116.1 \\
\hline 1367 & 1.37 & 2059619 & 68491391 & $\begin{array}{l}\text { gi|68491391|ref|XP_710493.1| NAD-dependent D-arabinitol dehydrogenase [Can- } \\
\text { dida albicans SC5314] }\end{array}$ & $8.26 \mathrm{E}-07$ & 14.9 & 5.5 & 30653.2 \\
\hline 1408 & -1.29 & 7767708 & 68469633 & $\begin{array}{l}\text { gi|68469633|ref|XP_721068.1| hypothetical protein CaO19_8442 [Candida albicans } \\
\text { SC5314] }\end{array}$ & 7.02E-06 & 11.6 & 5 & 21481.5 \\
\hline 1413 & -2.76 & 20017893 & 608690 & gi|608690|emb|CAA57342.1| alcohol dehydrogenase [Candida albicans] & $1.76 \mathrm{E}-07$ & 20.9 & 6 & 36856 \\
\hline 1414 & -4.71 & 22228723 & 608690 & gi|608690|emb|CAA57342.1| alcohol dehydrogenase [Candida albicans] & $2.14 \mathrm{E}-12$ & 23.7 & 6 & 36856 \\
\hline 1434 & -1.29 & 1478393 & 608690 & gi|608690|emb|CAA57342.1| alcohol dehydrogenase [Candida albicans] & $1.75 \mathrm{E}-08$ & 36.3 & 6 & 36856 \\
\hline 1450 & 1.63 & 5957463 & 68488457 & $\begin{array}{l}\text { gi|68488457|ref|XP_711912.1| hypothetical protein CaO19.8025 [Candida albicans } \\
\text { SC5314] (N-terminal of it) }\end{array}$ & 7.33E-14 & 27.5 & 5.4 & 47202.6 \\
\hline 1507 & & & 3850151 & gi|3850151|emb|CAA21951.1| rehydrin-like protein [Candida albicans] & $9.58 \mathrm{E}-10$ & 21.4 & 7.5 & 27458.3 \\
\hline \multirow[t]{2}{*}{1510} & 1.37 & 3122796 & 68468755 & gi|68468755|ref|XP_721436.1| phosphomannomutase [Candida albicans SC5314] & $1.43 \mathrm{E}-06$ & 14.3 & 5.4 & 29000.6 \\
\hline & & & 68468755 & gi|68468755|ref|XP_721436.1| phosphomannomutase [Candida albicans SC5314] & 4.36E-09 & 19.8 & 5.4 & 29000.6 \\
\hline \multirow[t]{2}{*}{1528} & 1.4 & 4811576 & 68469783 & $\begin{array}{l}\text { gi|68469783|ref|XP_721143.1| hypothetical protein CaO19_8522 [Candida albicans } \\
\text { SC5314] }\end{array}$ & $7.79 \mathrm{E}-09$ & 23 & 5.8 & 27437.5 \\
\hline & & & 68468755 & gi|68468755|ref|XP_721436.1| phosphomannomutase [Candida albicans SC5314] & $5.38 \mathrm{E}-12$ & 39.7 & 5.4 & 29000.6 \\
\hline 1539 & 1.41 & 6184612 & 68469783 & $\begin{array}{l}\text { gi|68469783|ref|XP_721143.1| hypothetical protein CaO19_8522 [Candida albicans } \\
\text { SC5314] }\end{array}$ & $8.34 \mathrm{E}-08$ & 31 & 5.8 & 27437.5 \\
\hline 1547 & 1.81 & 7292565 & 68469783 & $\begin{array}{l}\text { gi|68469783|ref|XP_721143.1| hypothetical protein CaO19_8522 [Candida albicans } \\
\text { SC5314] }\end{array}$ & $1.22 \mathrm{E}-09$ & 36.7 & 5.8 & 27437.5 \\
\hline 1565 & 1.38 & 1579898 & 68472685 & $\begin{array}{l}\text { gi|68472685|ref|XP_719661.1| putative mitochondrial complex I [Candida albicans } \\
\text { SC5314] }\end{array}$ & $1.16 \mathrm{E}-05$ & 16 & 7.9 & 27284.8 \\
\hline 1586 & 1.88 & 1040836 & 7270988 & gi|7270988|emb|CAB77631.1| triosephosphate isomerase [Candida albicans] & $1.61 \mathrm{E}-07$ & 23.8 & 5.7 & 26608.8 \\
\hline 1593 & 1.42 & 763906 & 68482810 & $\begin{array}{l}\text { gi|68482810|ref|XP_714631.1| hypothetical protein CaO19.8941 [Candida albicans } \\
\text { SC5314] }\end{array}$ & $2.99 \mathrm{E}-10$ & 17.9 & 5.5 & 23113.8 \\
\hline 1596 & 1.36 & 3094722 & 68470996 & $\begin{array}{l}\text { gi|68470996|ref|XP_720505.1| hypothetical protein CaO19_2755 [Candida albicans } \\
\text { SC5314] }\end{array}$ & 0.000197 & 15 & 5.5 & 14112.1 \\
\hline \multirow[t]{2}{*}{1627} & 1.65 & 1407978 & 68472462 & $\begin{array}{l}\text { gi|68472462|ref|XP_719792.1| glyceraldehyde-3-phosphate dehydrogenase [Candida } \\
\text { albicans SC5314] N-terminal }\end{array}$ & $1.64 \mathrm{E}-08$ & 20 & 6.7 & 35810.7 \\
\hline & & & 68479826 & $\begin{array}{l}\text { gi|68479826|ref|XP_716082.1| putative thioredoxin peroxidase [Candida albicans } \\
\text { SC5314] }\end{array}$ & $3.88 \mathrm{E}-11$ & 40.8 & 4.8 & 21846.3 \\
\hline
\end{tabular}


(Table 4) contd....

\begin{tabular}{|c|c|c|c|c|c|c|c|c|}
\hline $\begin{array}{c}\text { Spot } \\
\text { No. }\end{array}$ & $\begin{array}{c}\text { Average } \\
\text { Ratio** }^{*}\end{array}$ & $\begin{array}{l}\text { P - Spot } \\
\text { Vol. }\end{array}$ & Accession & Protein & $\begin{array}{c}\text { Protein } \\
\text { Probability }\end{array}$ & Coverage & pI & $\begin{array}{l}\text { Molecular } \\
\text { Weight }\end{array}$ \\
\hline 1666 & 1 & 16242598 & 68482234 & $\begin{array}{l}\text { gi|68482234|ref|XP_715001.1| hypothetical protein CaO19.11063 [Candida albicans } \\
\text { SC5314] }\end{array}$ & $4.59 \mathrm{E}-08$ & 37.3 & 6 & 25812.7 \\
\hline \multirow[t]{2}{*}{1693} & 1.11 & 2011633 & 68479826 & $\begin{array}{l}\text { gi|68479826|ref|XP_716082.1| putative thioredoxin peroxidase [Candida albicans } \\
\text { SC5314] }\end{array}$ & $5.31 \mathrm{E}-12$ & 25.5 & 4.8 & 21846.3 \\
\hline & & & 68472462 & $\begin{array}{l}\text { gi|68472462|ref|XP_719792.1| glyceraldehyde-3-phosphate dehydrogenase [Candida } \\
\text { albicans SC5314] N-terminal }\end{array}$ & $2.61 \mathrm{E}-09$ & 19.7 & 6.7 & 35810.7 \\
\hline \multirow[t]{2}{*}{1700} & -1.13 & 6273637 & 68482775 & $\begin{array}{l}\text { gi|68482775|ref|XP_714697.1| hypothetical protein CaO19.6991 [Candida albicans } \\
\text { SC5314] }\end{array}$ & $2.79 \mathrm{E}-08$ & 27.6 & 6.5 & 23286.5 \\
\hline & & & 68478409 & $\begin{array}{l}\text { gi|68478409|ref|XP_716706.1| putative heat shock protein regulator [Candida albi- } \\
\text { cans SC5314] }\end{array}$ & $1.81 \mathrm{E}-12$ & 17.7 & 4.8 & 17099.5 \\
\hline 1705 & -1.02 & 4023501 & 68468985 & $\begin{array}{l}\text { gi|68468985|ref|XP_721551.1| hypothetical protein CaO19_3053 [Candida albicans } \\
\text { SC5314] }\end{array}$ & $2.56 \mathrm{E}-09$ & 29.8 & 5 & 20310.4 \\
\hline 1741 & 1.03 & 4316714 & 68483469 & $\begin{array}{l}\text { gi|68483469|ref|XP_714295.1| putative glutathione peroxidase/redox transducer } \\
\text { [Candida albicans SC5314] }\end{array}$ & $1.30 \mathrm{E}-07$ & 33.5 & 6.9 & 18091.3 \\
\hline 1794 & 1.04 & 5507615 & 68470049 & $\begin{array}{l}\text { gi|68470049|ref|XP_720786.1| FKBP-type peptidyl-prolyl cis-trans isomerase Rbplp } \\
\text { [Candida albicans SC5314] }\end{array}$ & $3.30 \mathrm{E}-07$ & 18.5 & 7.1 & 13258.9 \\
\hline 1803 & -1.31 & 15541205 & 68470079 & $\begin{array}{l}\text { gi|68470079|ref|XP_720801.1| cyclophilin type peptidyl-prolyl cis-trans isomerase } \\
\text { [Candida albicans SC5314] }\end{array}$ & $5.15 \mathrm{E}-06$ & 25.3 & 8.2 & 17563.8 \\
\hline
\end{tabular}

*Ratio of biofilm:planktonic spot intensities

Table 5. Differentially Expressed Proteins in Cell Walls Isolated from C. albicans Biofilms Grown to Mature Phase and Planktonic Cells Grown to the Same Time Point

\begin{tabular}{|c|c|c|c|c|c|c|c|c|}
\hline $\begin{array}{l}\text { Spot } \\
\text { No. }\end{array}$ & $\begin{array}{l}\text { Average } \\
\text { Ratio* }\end{array}$ & $\begin{array}{l}\text { P - Spot } \\
\text { Vol. }\end{array}$ & $\begin{array}{l}\text { Accession } \\
\text { GI }\end{array}$ & Protein & $\begin{array}{c}\text { Protein } \\
\text { Probability }\end{array}$ & Coverage & pI & $\begin{array}{l}\text { Molecular } \\
\text { Weight }\end{array}$ \\
\hline 116 & -1.58 & 589363 & 68468339 & $\begin{array}{l}\text { gi|68468339|ref|XP_721729.1| putative fatty-acyl coenzyme A oxidase [Candida } \\
\text { albicans SC5314] }\end{array}$ & $5.08 \mathrm{E}-09$ & 7.1 & 5.6 & 78913.3 \\
\hline 120 & -2.3 & 709673 & 68468339 & $\begin{array}{l}\text { gi|68468339|ref|XP_721729.1| putative fatty-acyl coenzyme A oxidase [Candida } \\
\text { albicans SC5314] }\end{array}$ & 3.33E-07 & 5.5 & 5.6 & 78913.3 \\
\hline 126 & -2.26 & 434430 & 68488040 & $\begin{array}{l}\text { gi|68488040|ref|XP_712128.1| hypothetical protein CaO19.13993 [Candida albicans } \\
\text { SC5314] }\end{array}$ & $1.00 \mathrm{E}-05$ & 4.3 & 5.7 & 77290.6 \\
\hline 187 & -1.59 & 705455 & 68484803 & $\begin{array}{l}\text { gi|68484803|ref|XP_713713.1| putative acetyl CoA synthetase Acs2p [Candida } \\
\text { albicans SC5314] }\end{array}$ & $3.92 \mathrm{E}-07$ & 16.8 & 5.7 & 73815.5 \\
\hline \multirow[t]{2}{*}{195} & -1.99 & 1316446 & 68484803 & $\begin{array}{l}\text { gi|68484803|ref|XP_713713.1| putative acetyl CoA synthetase Acs2p [Candida } \\
\text { albicans SC5314] }\end{array}$ & $3.33 \mathrm{E}-07$ & 6.9 & 5.7 & 73815.5 \\
\hline & & & 68485837 & $\begin{array}{l}\text { gi|68485837|ref|XP_713199.1| mitochondrial import protein [Candida albicans } \\
\text { SC5314] }\end{array}$ & $2.73 \mathrm{E}-10$ & 12.7 & 5.3 & 69705.5 \\
\hline 209 & -2.51 & 2070709 & 607055 & gi $|607055| \mathrm{emb} \mid$ CAA82929.1| heat shock protein 70 [Candida albicans] & $2.75 \mathrm{E}-10$ & 18.3 & 4.9 & 70281.2 \\
\hline 210 & -1.79 & 551108 & 68479353 & $\begin{array}{l}\text { gi|68479353|ref|XP_716208.1| hypothetical protein CaO19_6367 [Candida albicans } \\
\text { SC5314] }\end{array}$ & $2.00 \mathrm{E}-08$ & 9 & 5.1 & 66408.6 \\
\hline \multirow[t]{3}{*}{234} & -3.35 & 2171433 & 68485837 & $\begin{array}{l}\text { gi|68485837|ref|XP_713199.1| mitochondrial import protein [Candida albicans } \\
\text { SC5314] }\end{array}$ & $1.40 \mathrm{E}-07$ & 13.1 & 5.3 & 69705.5 \\
\hline & & & 68478453 & $\begin{array}{l}\text { gi|68478453|ref|XP_716728.1| hypothetical protein CaO19_3419 [Candida albicans } \\
\text { SC5314] }\end{array}$ & $1.95 \mathrm{E}-11$ & 13.2 & 5.7 & 69700.6 \\
\hline & & & 2213423 & gi|2213423|emb|CAA66308.1| heat shock protein 70 [Candida albicans] & $6.34 \mathrm{E}-09$ & 5.9 & 5 & 66391.6 \\
\hline 239 & -4.84 & 3024764 & 3859677 & gi|3859677|emb|CAA22014.1| phenylalanyl-tRNA synthetase [Candida albicans] & $1.21 \mathrm{E}-08$ & 8.1 & 5.1 & 66779.4 \\
\hline 241 & -5.93 & 1792761 & 68478453 & $\begin{array}{l}\text { gi|68478453|ref|XP_716728.1| hypothetical protein CaO19_3419 [Candida albicans } \\
\text { SC5314] }\end{array}$ & $1.31 \mathrm{E}-05$ & 5.2 & 5.7 & 69700.6 \\
\hline \multirow[t]{2}{*}{242} & -5.65 & 2837226 & 2213423 & gi|2213423|emb|CAA66308.1| heat shock protein 70 [Candida albicans] & $1.97 \mathrm{E}-10$ & 6.4 & 5 & 66391.6 \\
\hline & & & 68478453 & $\begin{array}{l}\text { gi|68478453|ref|XP_716728.1| hypothetical protein CaO19_3419 [Candida albicans } \\
\text { SC5314] }\end{array}$ & $3.22 \mathrm{E}-10$ & 10.2 & 5.7 & 69700.6 \\
\hline
\end{tabular}


(Table 5) contd....

\begin{tabular}{|c|c|c|c|c|c|c|c|c|}
\hline $\begin{array}{l}\text { Spot } \\
\text { No. }\end{array}$ & $\begin{array}{l}\text { Average } \\
\text { Ratio* }^{*}\end{array}$ & $\begin{array}{l}\text { P - Spot } \\
\text { Vol. }\end{array}$ & $\begin{array}{l}\text { Accession } \\
\text { GI }\end{array}$ & Protein & $\begin{array}{c}\text { Protein } \\
\text { Probability }\end{array}$ & Coverage & pI & $\begin{array}{c}\text { Molecular } \\
\text { Weight }\end{array}$ \\
\hline & & & 68479353 & $\begin{array}{l}\text { gi|68479353|ref|XP_716208.1| hypothetical protein CaO19_6367 [Candida albicans } \\
\text { SC5314] }\end{array}$ & $1.38 \mathrm{E}-08$ & 5.5 & 5.1 & 66408.6 \\
\hline \multirow[t]{2}{*}{244} & -5.47 & 1226083 & 68480862 & $\begin{array}{l}\text { gi|68480862|ref|XP_715584.1| hypothetical protein CaO19_10389 [Candida albicans } \\
\text { SC5314] }\end{array}$ & $5.16 \mathrm{E}-08$ & 11.7 & 6 & 70131.6 \\
\hline & & & 68478453 & $\begin{array}{l}\text { gi|68478453|ref|XP_716728.1| hypothetical protein CaO19_3419 [Candida albicans } \\
\text { SC5314] }\end{array}$ & $8.28 \mathrm{E}-11$ & 4.8 & 5.7 & 69700.6 \\
\hline 245 & & & 68478796 & $\begin{array}{l}\text { gi|68478796|ref|XP_716560.1| hypothetical protein CaO19_1252 [Candida albicans } \\
\text { SC5314] }\end{array}$ & $1.67 \mathrm{E}-09$ & 6.4 & 7 & 75824 \\
\hline 250 & -5.15 & 941176 & 68480862 & $\begin{array}{l}\text { gi|68480862|ref|XP_715584.1| hypothetical protein CaO19_10389 [Candida albicans } \\
\text { SC5314] }\end{array}$ & 7.47E-07 & 7.6 & 6 & 70131.6 \\
\hline 342 & -1.88 & 4374340 & 68485963 & gi|68485963|ref|XP_713100.1| heat shock protein 60 [Candida albicans SC5314] & 1.47E-11 & 29.9 & 5.1 & 60088.7 \\
\hline 358 & 2.05 & 20379960 & 68480872 & gi|68480872|ref|XP_715589.1| pyruvate decarboxylase [Candida albicans SC5314] & $2.58 \mathrm{E}-11$ & 32.3 & 5.3 & 62402 \\
\hline \multirow[t]{2}{*}{408} & 1.65 & 15058075 & 68480872 & gi|68480872|ref|XP_715589.1| pyruvate decarboxylase [Candida albicans SC5314] & $3.40 \mathrm{E}-13$ & 34.6 & 5.3 & 62402 \\
\hline & & & 68488457 & $\begin{array}{l}\text { gi|68488457|ref|XP_711912.1| hypothetical protein CaO19.8025 [Candida albicans } \\
\text { SC5314] }\end{array}$ & $1.00 \mathrm{E}-30$ & 36.6 & 5.4 & 47202.6 \\
\hline \multirow[t]{2}{*}{782} & 1.71 & 5625470 & 68485391 & $\begin{array}{l}\text { gi|68485391|ref|XP_713373.1| O-acetylhomoserine O-acetylserine sulphydrylase } \\
\text { [Candida albicans SC5314] }\end{array}$ & 6.44E-14 & 20.9 & 5.5 & 47958.6 \\
\hline & & & 68488457 & $\begin{array}{l}\text { gi|68488457|ref|XP_711912.1| hypothetical protein CaO19.8025 [Candida albicans } \\
\text { SC5314] }\end{array}$ & 4.44E-14 & 36.8 & 5.4 & 47202.6 \\
\hline 784 & 1.64 & 13767138 & 68485391 & $\begin{array}{l}\text { gi|68485391|ref|XP_713373.1| O-acetylhomoserine O-acetylserine sulphydrylase } \\
\text { [Candida albicans SC5314] }\end{array}$ & $6.27 \mathrm{E}-13$ & 21.8 & 5.5 & 47958.6 \\
\hline 861 & & & 68489602 & $\begin{array}{l}\text { gi|68489602|ref|XP_711371.1| 3-phosphoglycerate kinase [Candida albicans } \\
\text { SC5314] }\end{array}$ & $4.40 \mathrm{E}-11$ & 44.4 & 6.1 & 45151.8 \\
\hline 862 & 1.73 & 3353727 & 68466811 & $\begin{array}{l}\text { gi|68466811|ref|XP_722601.1| aspartic-semi-aldehyde dehydrogenase [Candida } \\
\text { albicans SC5314] }\end{array}$ & $9.26 \mathrm{E}-10$ & 19.5 & 5.6 & 39200.4 \\
\hline 876 & 1.85 & 2345118 & 68489602 & $\begin{array}{l}\text { gi|68489602|ref|XP_711371.1| 3-phosphoglycerate kinase [Candida albicans } \\
\text { SC5314] }\end{array}$ & $1.47 \mathrm{E}-11$ & 30.9 & 6.1 & 45151.8 \\
\hline \multirow[t]{2}{*}{880} & 1.64 & 1594386 & 68489602 & $\begin{array}{l}\text { gi|68489602|ref|XP_711371.1|3-phosphoglycerate kinase [Candida albicans } \\
\text { SC5314] }\end{array}$ & $1.50 \mathrm{E}-12$ & 14.4 & 6.1 & 45151.8 \\
\hline & & & 68488457 & $\begin{array}{l}\text { gi|68488457|ref|XP_711912.1| hypothetical protein CaO19.8025 [Candida albicans } \\
\text { SC5314] }\end{array}$ & $2.55 \mathrm{E}-14$ & 37.5 & 5.4 & 47202.6 \\
\hline 885 & 2.49 & 6943451 & 68467327 & gi|68467327|ref|XP_722325.1| actin [Candida albicans SC5314] & $1.24 \mathrm{E}-11$ & 16.4 & 5.8 & 40154.2 \\
\hline \multirow[t]{3}{*}{1005} & 1.64 & 4250638 & 68473257 & $\begin{array}{l}\text { gi|68473257|ref|XP_719434.1| hypothetical protein CaO19_7676 [Candida albicans } \\
\text { SC5314] }\end{array}$ & $1.91 \mathrm{E}-12$ & 23.1 & 5.6 & 38746.7 \\
\hline & & & 68466123 & $\begin{array}{l}\text { gi|68466123|ref|XP_722836.1| fructose-bisphosphate aldolase [Candida albicans } \\
\text { SC5314] }\end{array}$ & $1.32 \mathrm{E}-12$ & 27.9 & 5.7 & 39190.8 \\
\hline & & & 68473257 & $\begin{array}{l}\text { gi|68473257|ref|XP_719434.1| hypothetical protein CaO19_7676 [Candida albicans } \\
\text { SC5314] }\end{array}$ & $6.08 \mathrm{E}-12$ & 19.2 & 5.6 & 38746.7 \\
\hline \multirow[t]{3}{*}{1026} & 1.68 & 3688268 & 68476713 & gi|68476713|ref|XP_717649.1| alcohol dehydrogenase 2 [Candida albicans SC5314] & 3.45E-07 & 19.5 & 6.3 & 36784.1 \\
\hline & & & 608690 & gi|608690|emb|CAA57342.1| alcohol dehydrogenase [Candida albicans] & $8.81 \mathrm{E}-12$ & 36.6 & 6 & 36856 \\
\hline & & & 68473257 & $\begin{array}{l}\text { gi|68473257|ref|XP_719434.1| hypothetical protein CaO19_7676 [Candida albicans } \\
\text { SC5314] }\end{array}$ & $2.04 \mathrm{E}-11$ & 20.6 & 5.6 & 38746.7 \\
\hline
\end{tabular}


(Table 5) contd....

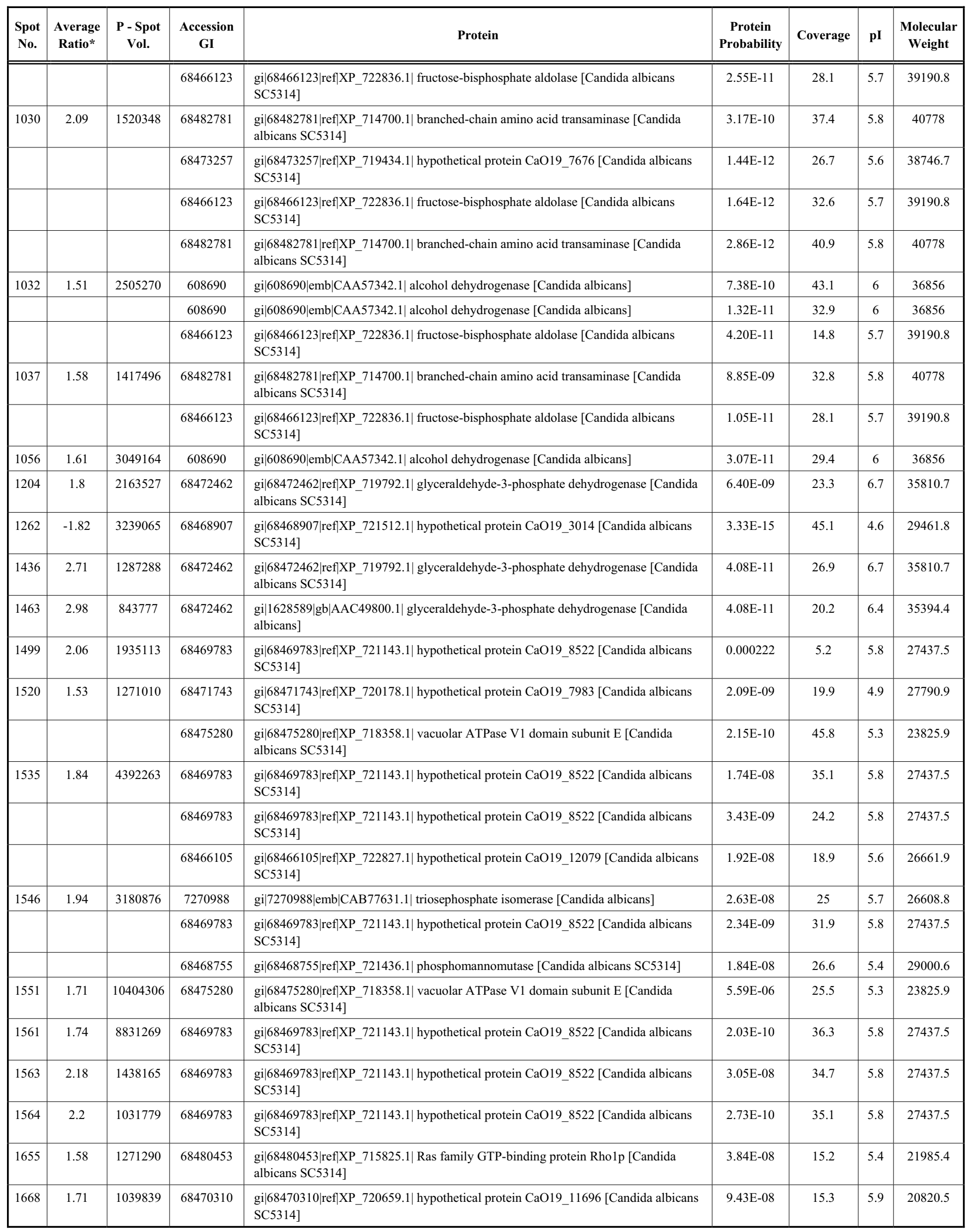


(Table 5) contd...

\begin{tabular}{|c|c|c|c|c|c|c|c|c|}
\hline $\begin{array}{l}\text { Spot } \\
\text { No. }\end{array}$ & $\begin{array}{l}\text { Average } \\
\text { Ratio* }\end{array}$ & $\begin{array}{l}\text { P - Spot } \\
\text { Vol. }\end{array}$ & $\begin{array}{l}\text { Accession } \\
\quad \text { GI }\end{array}$ & Protein & $\begin{array}{c}\text { Protein } \\
\text { Probability }\end{array}$ & Coverage & pI & $\begin{array}{l}\text { Molecular } \\
\text { Weight }\end{array}$ \\
\hline 1703 & 2.41 & 3503757 & 68479834 & $\begin{array}{l}\text { gi|68479834|ref|XP_716086.1| hypothetical protein CaO19_7421 [Candida albicans } \\
\text { SC5314] }\end{array}$ & $2.33 \mathrm{E}-14$ & 12.7 & 6.3 & 25341.8 \\
\hline 1704 & 1.55 & 2852610 & 68482775 & $\begin{array}{l}\text { gi|68482775|ref|XP_714697.1| hypothetical protein CaO19.6991 [Candida albicans } \\
\text { SC5314] }\end{array}$ & $8.61 \mathrm{E}-07$ & 11.7 & 6.5 & 23286.5 \\
\hline 1710 & 1.85 & 11010304 & 68491679 & $\begin{array}{l}\text { gi|68491679|ref|XP_710366.1| hypothetical protein CaO19.5285 [Candida albicans } \\
\text { SC5314] }\end{array}$ & $7.88 \mathrm{E}-05$ & 10.1 & 5.8 & 21160.9 \\
\hline 1776 & 1.63 & 9594945 & 68473729 & $\begin{array}{l}\text { gi|68473729|ref|XP_719189.1| ubiquinol cytochrome-c reductase subunit } 7 \text { [Candida } \\
\text { albicans SC5314] }\end{array}$ & $6.74 \mathrm{E}-06$ & 25.2 & 5.7 & 14414.6 \\
\hline
\end{tabular}

Table 6. Differentially Expressed Pathways in Matrix and Cell Walls Isolated from C. albicans Biofilms Grown to Early and Mature Developmental Phases

\begin{tabular}{|c|c|c|}
\hline Protein Sample & Early Phase (6 h) & Mature Phase (48 h) \\
\hline Matrix & $\begin{array}{l}\text { Purine metabolism } \\
\text { Fructose and mannose metabolism } \\
\text { Pentose phosphate pathway } \\
\text { Glycine, serine and threonine metabolism } \\
\text { Glycolysis / Gluconeogenesis } \\
\text { Biosynthesis of steroids } \\
\text { Urea cycle and metabolism of amino groups } \\
\text { Glutamate metabolism* } \\
\text { Methionine metabolism } \\
\text { Valine, leucine and isoleucine biosynthesis } \\
\text { Lysine biosynthesis } \\
\text { beta-Alanine metabolism } \\
\text { Glycerolipid metabolism } \\
\text { Glycerophospholipid metabolism } \\
\text { Pantothenate and CoA biosynthesis } \\
\text { Terpenoid biosynthesis } \\
\text { Nitrogen metabolism* } \\
\text { Calcium signaling pathway }\end{array}$ & $\begin{array}{l}\text { Fructose and mannose metabolism } \\
\text { Purine metabolism* } \\
\text { Glycolysis / Gluconeogenesis } \\
\text { Pentose phosphate pathway } \\
\text { Glycine, serine and threonine metabolism* } \\
\text { Carbon fixation* } \\
\text { Inositol metabolism* } \\
\text { Biosynthesis of steroids } \\
\text { Urea cycle and metabolism of amino groups } \\
\text { Methionine metabolism } \\
\text { Valine, leucine and isoleucine biosynthesis } \\
\text { Lysine biosynthesis } \\
\text { beta-Alanine metabolism } \\
\text { Glycerolipid metabolism } \\
\text { Glycerophospholipid metabolism } \\
\text { Pantothenate and CoA biosynthesis } \\
\text { Terpenoid biosynthesis } \\
\text { Calcium signaling pathway }\end{array}$ \\
\hline Cell walls & $\begin{array}{l}\text { Glycolysis / Gluconeogenesis } \\
\text { Fructose and mannose metabolism } \\
\text { Inositol metabolism } \\
\text { Fatty acid metabolism } \\
\text { Bile acid biosynthesis } \\
\text { Oxidative phosphorylation } \\
\text { Valine, leucine and isoleucine degradation } \\
\text { Valine, leucine and isoleucine biosynthesis } \\
\text { Lysine biosynthesis } \\
\text { Lysine degradation } \\
\text { Tyrosine metabolism } \\
\text { Phenylalanine, tyrosine and tryptophan biosynthesis } \\
\text { Glycerolipid metabolism } \\
\text { 1- and 2-Methylnaphthalene degradation } \\
\text { 3-Chloroacrylic acid degradation } \\
\text { Carbon fixation } \\
\text { Pantothenate and CoA biosynthesis }\end{array}$ & $\begin{array}{l}\text { Glycolysis / Gluconeogenesis } \\
\text { Fructose and mannose metabolism } \\
\text { Fatty acid metabolism } \\
\text { Oxidative phosphorylation } \\
\text { Carbon fixation } \\
\text { Inositol metabolism } \\
\text { Aminoacyl-tRNA biosynthesis* } \\
\text { PPAR signaling pathway* } \\
\text { Citrate cycle (TCA cycle)* } \\
\text { Pentose phosphate pathway* } \\
\text { Bile acid biosynthesis } \\
\text { Glycine, serine and threonine metabolism* } \\
\text { Methionine metabolism* } \\
\text { Cysteine metabolism* } \\
\text { Valine, leucine and isoleucine degradation } \\
\text { Valine, leucine and isoleucine biosynthesis } \\
\text { Lysine biosynthesis } \\
\text { Arginine and proline metabolism* } \\
\text { Tyrosine metabolism } \\
\text { Phenylalanine, tyrosine and tryptophan biosynthesis } \\
\text { Glycerolipid metabolism } \\
\text { alpha-Linolenic acid metabolism* } \\
\text { Pyruvate metabolism* } \\
\text { 1- and 2-Methylnaphthalene degradation } \\
\text { 3-Chloroacrylic acid degradation } \\
\text { Pantothenate and CoA biosynthesis } \\
\text { Metabolism of xenobiotics by cyt-P450* } \\
\text { Polyunsaturated fatty acid biosynthesis* } \\
\text { Proteasome* } \\
\text { Type III secretion system* } \\
\text { Calcium signaling pathway* }\end{array}$ \\
\hline
\end{tabular}

*Phase-specific pathways overexpressed specifically in matrix or cell walls of early or mature biofilms. 

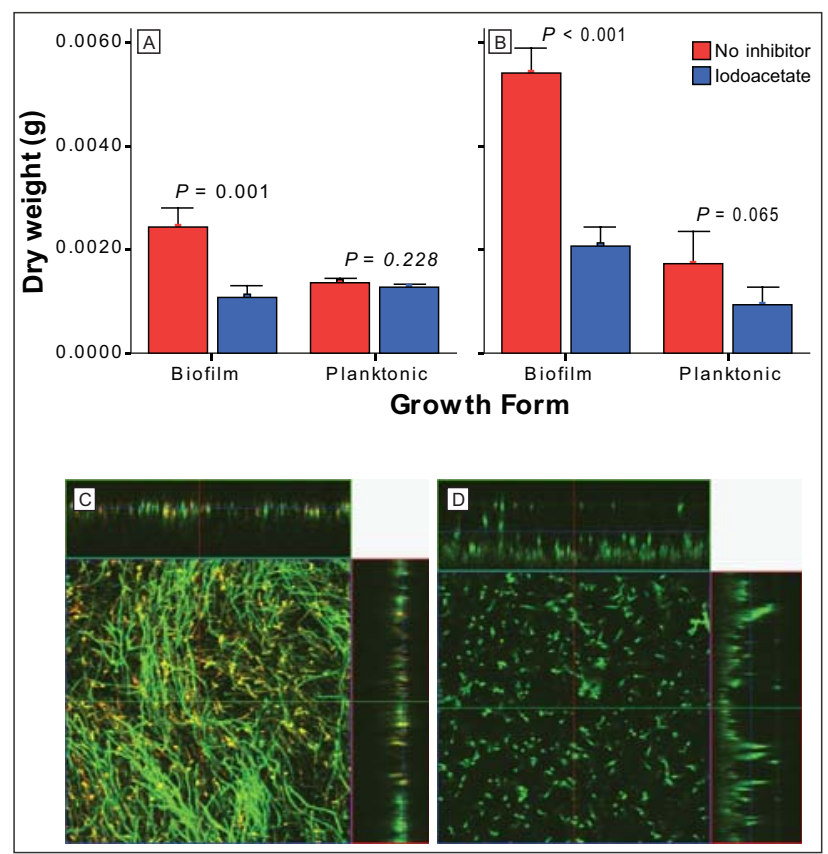

Fig. (8). Effect of GAPDH inhibitor sodium iodoacetate on the ability of $\boldsymbol{C}$. albicans to form biofilms. (A-B) Dry weight determination of biofilm grown to (A) early or (B) mature phase. (C-D) Confocal microscopy images of mature biofilms grown in the $(\mathrm{C})$ absence or (D) presence of sodium iodoacetate. Panels C and D show top-down images obtained after three-dimensional reconstruction of all the $z$-stacks resulting from the confocal analyses.

analyses revealed the presence of proteins like transcription factors (e.g. translation initiation factor eIF4A subunit), DNA binding proteins (e.g. HSP70, PDR, BMH1), NTPase activity (RHO1), and kinases (e.g. BCY1) with regulatory functions, which are expected to be present at low levels.

Traditional 2D-GE approach has been earlier used to analyze protein profile of Candida cells. In one such study, Kusch et al. [36] performed 2D-GE proteomic analysis of planktonically grown $C$. albicans yeast cells to exponential and stationary growth phases, and used similar tools to identify several differentially expressed pathways in a growth phase dependent manner. In a separate study, Thomas et al. [15] reported the use of conventional 2D-GE-based proteomics for the comparative analysis of the protein profiles of surface-associated and secreted proteins obtained from mature biofilm and planktonic cultures of C. albicans. These investigators reported that 9 surface-associated and 34 secreted proteins were differentially expressed in biofilms. In contrast, our DIGE analyses revealed much higher number of differentially expressed proteins in mature $C$. albicans biofilms (35 cell wall-associated and 56 extracellular matrixassociated proteins were differentially expressed, of which 24 and 54 were upregulated, respectively) and early phase biofilms.

The higher number of differentially expressed proteins detected in our studies compared to those reported by Thomas et al. [15] may be attributed to the fact that the methods used by these investigators for protein extraction and gel electrophoresis were different from those used in our study. In this regard, Rathsam et al. [9] showed that compared with 2D-GE proteome analysis, DIGE analysis resulted in a 3- fold increase in the number of identified protein spots that were significantly altered in their level of expression in biofilms formed by Streptococcus mutans. Additionally, we used an EDTA-based extraction method which resulted in higher protein yield than the vortexing method, which also likely contributed to the differences in protein profiles between the two studies.

Another probable reason for the difference in protein profile observed in our study compared to that reported by Thomas et al. [15] is that in our study, biofilms were formed on serum-pre-coated catheter discs, while these investigators analyzed biofilms grown in tissue culture flasks. In this regard, it is notable that different surface types induce distinct differences in biofilm morphology and architecture [31], and could also account for the observed differences in protein profiles between the two studies.

A common concern with systems biology "omics" approaches (e.g. proteomics, genomics, metabolomics) is an abundance of data points which are not mined properly to arrive at an over-arching global perspective of cellular functions [37, 38]. To gain insight into cellular functions involved in Candida biofilms, we used online Omics (based on a $S$. cerevisiae database) and KEGG pathway analysis tools (incorporating a pre-existing, online C. albicans dataset) [28] to map the differentially expressed proteins to specific pathways. These analyses revealed that proteins associated with several pathways were differentially expressed in $C$. albicans biofilms at early and mature phases, and suggested a general trend of increased expression of metabolic pathway proteins during biofilm formation. We also found that although the same pathways (e.g. glycolysis) may be differentially expressed at both early and mature phases in biofilms, the number and identity of the actual proteins involved in these pathways may differ considerably between the two phases. Such changes in the number and identity of differentially expressed proteins involved in carbohydrate and amino acid metabolism, and in the calcium and PPAR signaling pathways may account for the dramatic increase observed in metabolic activity and matrix production in mature biofilms. This increase is not surprising since it is expected that different functional processes may be operative at different biofilm developmental phases. Such phase-specific expression of pathways may be critical for increased production of cell walls, extracellular matrix, and the observed antifungal resistance associated with mature biofilms. While a majority of the differentially expressed proteins identified in the current study are involved in metabolic pathways, it is also possible that these proteins may play non-metabolic roles in biofilm formation. In this regard, several enzymatic proteins have been shown to play diverse unrelated functions like control of gene expression, organelle assembly, and modification of the activity of metabolic pathways (reviewed in [39]). The role played by differentially expressed proteins in biofilm formation by $C$. albicans remains to be investigated.

We found that glycolysis/gluconeogenesis was the most common pathway that was differentially expressed at both early and mature phases of biofilm development. Other pathways that were differentially expressed (mostly upregulated) during biofilm formation included pentose phosphate pathway, tricarboxylic acid (TCA) cycle, amino acid metabolism, and sterol biosynthesis. Since several of the up- 
regulated pathways are involved in carbohydrate metabolism, it is possible that such up-regulation is associated with increased cell wall and matrix synthesis - two functional processes known to occur during C. albicans biofilm formation. Previously, several microarray studies described changes in gene expression during early phase of biofilm development [40-43]. These studies demonstrated that genes involved in carbohydrate assimilation, amino acid metabolism, and intracellular transport mechanisms were overexpressed during the early phase of biofilm formation. Our proteomic data are in agreement with the overall trend seen in these microarray studies, although the specific genes and proteins did not always correlate. Interestingly, in one of the microarray studies reported by our group [40] it was shown that at mature phase $(48 \mathrm{~h})$, few genes were differentially expressed, suggesting a relative lack of initiation of new metabolic activity at the transcriptional level. However, in the current study we observed active metabolic processes occurring at the mature phase. The difference between the microarray data and our proteomic analyses may be due to the fact that cellular processes in Candida cells are known to be regulated differently at the transcriptional and translational levels, and similar differential regulation of pathways involved in cell wall biogenesis, general metabolism and signaling events is likely to occur in mature Candida biofilms. Another reason for the difference between previous microarray results and our current proteomic results could be the fact that mRNAs and proteins have different stabilities [44, 45], In this regard, Belle et al. [45] suggested that transient changes in the abundance of mRNAs coding for stable proteins may take significant time to induce comparable changes in protein abundance. Taken together, our results demonstrate that $C$. albicans biofilm formation is associated with changes in protein profiles belonging to different yet interconnected metabolic pathways. Our proteomic analyses also demonstrated that information obtained using proteomics complements that generated from transcriptional profiling, and can be used to glean comprehensive insight into the phase-dependent processes operative during the biofilm formation. Moreover, these results show that biofilm formation is a dynamic process, with changes at both mRNA and protein levels occuring at different developmental phases.

Our studies demonstrated that glycolysis was one of the pathways overexpressed in biofilms at both early and mature phases, and that GAPDH was the most overexpressed glycolytic enzyme in biofilms at both developmental phases. Moreover, inhibition of GAPDH using iodoacetate (a specific and irreversible inhibitor) resulted in abrogation of the ability of $C$. albicans to form biofilms. Confocal analyses confirmed such effect of this inhibitor on biofilm formation. Interestingly, iodoacetate specifically inhibited C. albicans biofilms grown to early or mature phases but had not significant effect on planktonic cells grown to similar time points. These results suggest that GAPDH may play a specific role in biofilm formation, unrelated to normal fungal growth. In this regard, Solem et al. [30] previously showed that GAPDH has no control over glycolytic flux in growing cells of Lactococcus lactis. It is possible that a similar situation exists in planktonically grown C. albicans, where inhibition of GAPDH may be compensated by other enzymes of the pathway. However, in biofilm mode of growth, GAPDH may exert its inhibition of glycolysis, thereby also reducing biofilm formation. The role of GAPDH in biofilm formation needs to be further confirmed by targeted disruption of the gene encoding this protein. The mechanism/s by which phase-associated pathways (e.g. glycolysis/gluconeogenesis) and enzymes like GAPDH regulate C. albicans biofilm formation is unknown and is currently under investigation.

Overall, our studies revealed that specific metabolic pathways are differentially expressed in C. albicans biofilms in a phase-dependent manner. These pathways and associated proteins may play critical roles in Candida biofilm formation, and represent potential targets for designing antibiofilm drugs, as well as for early diagnosis of infections associated with Candida biofilms.

\section{ACKNOWLEDGMENTS}

This work was supported by funds from the American Heart Association (Scientist Development Grant 0335313N) Award to PKM, National Institutes of Health (R01 DE017486-01A1, R01DE 13932-4) to MAG, and the Bristol Myers Squibb Freedom to Discover Award to MAG. Assistance of the Confocal Scanning Laser Microscopy core facility (NCI grant P30CA43703-12) at Case Western Reserve University is gratefully acknowledged. The authors thank William J. Halsall for technical assistance.

\section{REFERENCES}

[1] Edmond, M. B.; Wallace, S. E.; McClish, D. K.; Pfaller, M. A.; Jones, R. N.; Wenzel, R. P. Clin. Infect. Dis., 1999, 29, 239.

[2] Wisplinghoff, H.; Bischoff, T.; Tallent, S. M.; Seifert, H.; Wenzel, R. P.; Edmond, M. B. Clin. Infect. Dis., 2004, 39, 309.

[3] Almirante, B.; Rodriguez, D.; Park, B. J.; Cuenca-Estrella, M.; Planes, A. M.; Almela, M.; Mensa, J.; Sanchez, F.; Ayats, J.; Gimenez, M.; Saballs, P.; Fridkin, S. K.; Morgan, J.; RodriguezTudela, J. L.; Warnock, D. W.; Pahissa, A.; the Barcelona Candidemia Project Study Group. J. Clin. Microbiol., 2005, 43, 1829.

[4] Gudlaugsson, O.; Gillespie, S.; Lee, K.; Vande, B. J.; Hu, J.; Messer, S.; Herwaldt, L.; Pfaller, M.; Diekema, D. Clin. Infect. Dis., 2003, 37, 1172.

[5] Mermel, L. A.; Farr, B. M.; Sherertz, R. J.; Raad, I. I.; O'Grady, N.; Harris, J. S.; Craven, D. E. Clin. Infect. Dis., 2001, 32, 1249.

[6] O'Grady, N. P.; Alexander, M.; Dellinger, E. P.; Gerberding, J. L.; Heard, S. O.; Maki, D. G.; Masur, H.; McCormick, R. D.; Mermel, L. A.; Pearson, M. L.; Raad, I. I.; Randolph, A.; Weinstein, R. A. MMWR Recomm. Rep., 2002, 51, 1 .

[7] Chandra, J.; Kuhn, D. M.; Mukherjee, P. K.; Hoyer, L. L.; McCormick, T.; Ghannoum, M. A. J. Bacteriol., 2001, 183, 5385.

[8] Kuhn, D. M.; George, T.; Chandra, J.; Mukherjee, P. K.; Ghannoum, M. A. Antimicrob. Agents Chemother., 2002, 46, 1773.

[9] Rathsam, C.; Eaton, R. E.; Simpson, C. L.; Browne, G. V.; Valova, V. A.; Harty, D. W. S.; Jacques, N. A. J. Proteome Res., 2005, 4, 2161

[10] Resch, A.; Leicht, S.; Saric, M.; Pasztor, L.; Jakob, A.; Gotz, F.; Nordheim, A. Proteomics, 2006, 6, 1867.

[11] Riedel, K.; Arevalo-Ferro, C.; Reil, G.; Gorg, A.; Lottspeich, F.; Eberl, L. Electrophoresis, 2003, 24, 740 .

[12] Sauer, K.; Camper, A. K. J. Bacteriol., 2001, 183, 6579.

[13] Tremoulet, F.; Duche, O.; Namane, A.; Martinie, B.; Labadie, J. C. FEMS Microbiol. Lett., 2002, 215, 7.

[14] Mukherjee, P. K.; Mohamed, S.; Chandra, J.; Kuhn, D.; Liu, S.; Antar, O. S.; Munyon, R.; Mitchell, A. P.; Andes, D.; Chance, M. R.; Rouabhia, M.; Ghannoum, M. A. Infect. Immun., 2006, 74, 3804.

[15] Thomas, D. P.; Bachmann, S. P.; Lopez-Ribot, J. L. Proteomics, 2006, 6, 5795 .

[16] Mackintosh, J. A.; Choi, H. Y.; Bae, S. H.; Veal, D. A.; Bell, P. J.; Ferrari, B. C.; Van Dyk, D. D.; Verrills, N. M.; Paik, Y. K.; Karuso, P. Proteomics, 2003, 3, 2273. 
[17] Chandra, J.; Mukherjee, P. K.; Leidich, S. D.; Faddoul, F. F.; Hoyer, L. L.; Douglas, L. J.; Ghannoum, M. A. J. Dent. Res., 2001, 80,903 .

[18] Mukherjee, P. K.; Zhou, G.; Mohamed, S.; Chandra, J.; Ghannoum, M. A. Presented at 7th ASM Conference on Candida and Candidiasis. 2004 March 18-22. Austin, TX, American Society for Microbiology: Abstract 160

[19] Mukherjee, P. K.; Chandra, J.; Kuhn, D. M.; Walker, C. A.; Ghannoum, M. A. Presented at 6th ASM Conference on Candida and Candidiasis. January 13-17, 2002. Tampa, FL, American Society for Microbiology: Abstract 125.

[20] Mukherjee, P. K.; Prasad, R. Yeast, 1998, 14, 335.

[21] de Groot, P. W. J.; de Boer, A. D.; Cunningham, J.; Dekker, H. L.; de Jong, L.; Hellingwerf, K. J.; de Koster, C.; Klis, F. M. Eukar. Cell, 2004, 3, 955.

[22] Pitarch, A.; Sanchez, M.; Nombela, C.; Gil, C. Molec. Cell. Proteom., 2002, 1, 967.

[23] Dubois, M.; Gilles, K. A.; Hamilton, J. K.; Rebers, P. A.; Smith, F. Anal. Chem., 1956, 28, 350

[24] Gendimenico, G. J.; Bouquin, P. L.; Tramposch, K. M. Anal. Biochem., 1988, 173, 45.

[25] Eisen, M. B.; Spellman, P. T.; Brown, P. O.; Botstein, D. Proc. Natl. Acad. Sci. USA, 1998, 95, 14863.

[26] Saldanha, A. J. Bioinformatics, 2004, 20, 3246.

[27] Perkins, D. N.; Pappin, D. J.; Creasy, D. M.; Cottrell, J. S. Electrophoresis, 1999, 20, 3551.

[28] Kanehisa, M.; Goto, S. Nucleic Acids Res., 2000, 28, 27.

[29] Poolman, B.; Bosman, B.; Kiers, J.; Konings, W. N. J. Bacteriol., $1987,169,5887$.

[30] Solem, C.; Koebmann, B. J.; Jensen, P. R. J. Bacteriol., 2003, 185, 1564.
[31] Chandra, J.; Patel, J. D.; Li, J.; Zhou, G.; Mukherjee, P. K.; McCormick, T. S.; Anderson, J. M.; Ghannoum, M. A. Appl. Environ. Microbiol., 2005, 71, 8795 .

[32] Petersen, F. C.; Tao, L.; Scheie, A. A. J Bacteriol, 2005, 187, 4392.

[33] Walker, T. S.; Tomlin, K. L.; Worthen, G. S.; Poch, K. R.; Lieber, J. G.; Saavedra, M. T.; Fessler, M. B.; Malcolm, K. C.; Vasil, M. L.; Nick, J. A. Infect. Immun., 2005, 73, 3693.

[34] Al-Fattani, M. A.; Douglas, L. J. J. Med. Microbiol., 2006, 55, 999.

[35] Zhang, X.; Bishop, P. L.; Kinkle, B. K. Water Sci. Technol., 1999, $39,211$.

[36] Kusch, H.; Engelmann, S.; Bode, R.; Albrecht, D.; Morschhauser, J.; Hecker, M. Int. J. Med. Microbiol., 2008, 298, 291.

[37] Larsson, O.; Wennmalm, K.; Sandberg, R. OMICS, 2006, 10, 381.

[38] Oldiges, M.; Lütz, S.; Pflug, S.; Schroer, K.; Stein, N.; Wiendahl, C. Appl. Microbiol. Biotechnol., 2007, 76, 495.

[39] Gancedo, C.; Flores, C.-L. Microbiol. Molec. Biol. Rev., 2008, 72 , 197.

[40] Yeater, K. M.; Chandra, J.; Cheng, G.; Mukherjee, P. K.; Zhao, X.; Rodriguez-Zas, S. L.; Kwast, K. E.; Ghannoum, M. A.; Hoyer, L. L. Microbiology, 2007, 153, 2373.

[41] Murillo, L. A.; Newport, G.; Lan, C.-Y.; Habelitz, S.; Dungan, J.; Agabian, N. M. Eukar. Cell, 2005, 4, 1562.

[42] Nobile, C. J.; Mitchell, A. P. Curr. Biol., 2005, 15, 1150.

[43] Garcia-Sanchez, S.; Aubert, S.; Iraqui, I.; Janbon, G.; Ghigo, J. M.; d'Enfert, C. Eukar. Cell, 2004, 3, 536.

[44] Kebaara, B. W.; Nielsen, L. E.; Nickerson, K. W.; Atkin, A. L. Genome, 2006, 49, 894.

[45] Belle, A.; Tanay, A.; Bitincka, L.; Shamir, R.; O'Shea, E. K. Proc. Natl. Acad. Sci. USA, 2006, 103, 13004. 